\title{
Conjugated Linoleic Acid (CLA) content of meat from three muscles of Massese suckling lambs slaughtered at different weights
}

\author{
A. Serra ${ }^{1}$, M. Mele ${ }^{1}$, F. La Comba ${ }^{1}$, G. Conte ${ }^{1}$, A. Buccioni ${ }^{2}$ and P. Secchiari ${ }^{1}$ \\ ${ }^{1}$ Dipartimento di Agronomia e Gestione dell'Agroecosistema Sezione Scienze Zootecniche, \\ Università di Pisa, Via del Borghetto 80, 56124 Pisa, Italy \\ ${ }^{2}$ Dipartimento di Scienze Zootecniche, Università di Firenze, Via delle Cascine 5, 50100 \\ Firenze, Italy
}

\begin{abstract}
Eighteen Massese male lambs, fed mainly maternal milk were slaughtered at 11, 14 and 17 kg. Samples of Longissimus Dorsi (LD), Triceps Brachii (TB) and Semimembranosus (Sm) muscles were collected. Milk from the lamb's dams was sampled weekly. Fatty acid composition of milk and meat was determined.

TB was the fattest muscle, Sm the leanest one and LD showed an intermediate value of total lipids, while the weight at slaughter did not influence total intramuscular fat content in any muscle. Although slaughter weight slightly affected overall fatty acid composition of muscles, rumenic acid and total CLA content in TB and Sm, but not in LD, significantly increased with slaughter weight. As regard milk fatty acid composition, the contents of total CLA, RA and others minor CLA isomers decreased during the first four weeks after lambing and then increased at the last control (five weeks). The animals slaughtered at a live weight of 14 and $17 \mathrm{~kg}$ showed a greater SCD enzyme activity (estimated by product/substrate ratio) and a higher rumen activity (estimated by means of branched chain and odd chain fatty acid content in meat) than animals slaughtered at $11 \mathrm{~kg}$. Cis-7, trans-9 CLA content significantly increased with the slaughter age in TB and SM, while trans-7, trans-9 CLA, only increased in TB, and cis-8, cis-10 CLA, only increased in SM. Further studies are needed in order to verify weather the different behaviour of RA in LD muscle may be due to differences in muscle metabolism or fatty acid utilisation.
\end{abstract}

Keywords: Lamb; Meat; Massese breed; Fatty acid; CLA; Muscle 


\section{Introduction}

Conjugated Linoleic Acid (CLA) is a collective term for different positional and geometric isomers of octadecadienoic acid which contain a pair of double bonds in a conjugated configuration. Numerous health benefits have been attributed to single CLA isomers in experimental animal models, including actions to reduce carcinogenesis, atherosclerosis, onset of diabetes, and body fat mass (Belury, 2002, Ip et al., 1999, Lee et al., 1994 and Parodi, 1997). Major dietary sources of CLA are foods from ruminants, especially dairy products, where cis-9, trans-11 18:2, also named rumenic acid (RA) (Kramer et al., 1998) is the predominant CLA isomer.

The characteristics of lamb carcasses produced on the west coast of Italy are unique. In this area, in fact, lamb meat originates from dairy ovine breeds, and lambs are slaughtered very young, after a suckling period of 20-30 days, in order to minimize the milk loss for cheese production and also because Italian consumers prefer this kind of product. From birth to slaughter, lambs are managed with their mothers and are fed almost exclusively on milk. As a matter of fact, also small amounts of roughage may be ingested, when lambs follow their mothers at pasture. This kind of management may be assumed as standard for Italian dairy ewes. The Massese sheep originates from Tuscany (Italy) and it is the third dairy ovine breed in Italy in terms of the size of population. Massese lambs are normally slaughtered at a live weight ranging from 11 to $14 \mathrm{~kg}$, but they can also produce heavier carcasses, provided that the increase in slaughtered weight does not compromise meat quality, and that the length of the suckling period does not exceed 30 days.

The effect of the feeding regimen on the fatty acid composition of lamb meat has been previously considered (Nurnberg, Wegner, \& Ender, 1998), and some studies have also taken into consideration the content of RA and trans-10, cis-12 CLA in the intramuscular fat (Santos-Silva, Bessa, \& Santos-Silva, 2002). Nevertheless, little is known about the effect of the typical Italian rearing system on the meat content of CLA isomers, when the feeding regimen consists mainly of suckled milk.

The aim of this trial was to evaluate the effect of the slaughter weight on the CLA isomer content of intramuscular fat in three different kind of muscles, Longissimus dorsi (LD), Triceps brachii (TB) and Semimembranosus (Sm). This was achieved by taking into consideration also the milk composition of the ewes during the whole suckling period. 


\section{Materials and methods}

\section{Animals}

The study was carried out on 18 male suckling Massese lambs in a dairy farm located in West-Tuscany (Italy). No twins were considered. Lambs were born in the spring and at birth were randomly divided into 3 groups of 6 animals. The first group was slaughtered at $11 \mathrm{~kg}(11.2 \pm 0.5)$ when the lambs were nearly 14 days old, while the animals belonging to the other two groups were slaughtered at $14 \mathrm{~kg}(14.1 \pm 0.4)$ and at $17 \mathrm{~kg}(17.0 \pm 0.5)$, when the lambs were, respectively, nearly 21 and 28 days old. During the whole experimental period lambs were kept with their mother and they were fed mainly maternal milk. Every day lambs followed their mothers as they grazed pasture. The ewes were fed only pasture that was composed by following botanic species: $50 \%$ grass; $25 \%$ clovers; $25 \%$ other species. The fatty acid composition of pasture, on percentage of total fatty acids basis, was the following: $\mathrm{C}_{12: 0}, 0.18 ; \mathrm{C}_{14: 0}, 0.45 ; \mathrm{C}_{15: 0}, 0.15 ; \mathrm{C}_{16: 0}, 16.88 ; \mathrm{C}_{17: 0}, 0.16 ; \mathrm{C}_{18: 0}, 2.01 ; \mathrm{C}_{18: 1}$ ${ }_{c 9}, 2.67 ; \mathrm{C}_{18: 2 n-6}, 19.36 ; \mathrm{C}_{18: 3 n-3}, 55.77, \mathrm{C}_{20: 0}, 0.54 ; \mathrm{C}_{20: 3 n-3}, 0.42 ; \mathrm{C}_{23: 0}, 0.16 ; \mathrm{C}_{23: 0}, 0.16$; $\mathrm{C}_{24: 0}, 0.49$.

\section{Muscle sampling}

When the lambs reached the slaughter weight they were electrically stunned and slaughtered by exsanguinations in a public abattoir. Carcasses were immediately transferred to a cooler at $4{ }^{\circ} \mathrm{C}$ and after a conservation period of $24 \mathrm{~h}$, samples of Longissimus dorsi (LD), Triceps brachii (TB) and Semimembranosus (Sm) muscles were collected from the right side of each carcass. The sample of LD was drawn at the level of 13th thoracic rib, while complete TB and Sm were removed. Muscle samples included the muscle tissue, epimysium and the adipose tissue. Samples were vacuum packaged and stored at $-20{ }^{\circ} \mathrm{C}$ until analysis.

\section{Milk sampling}

During the whole experimental period, the maternal milk of each lamb was sampled weekly. Milk samples $(50 \mathrm{ml})$ were taken grouping the ewes according to day of respective lambing: If the time exceeded 3 days the milk was sampled in another day of week. Milk was sampled at 7.00 a.m. after the udder was completely emptied. After mixing, an aliquot of $50 \mathrm{ml}$ was sampled and stored at $-20{ }^{\circ} \mathrm{C}$ until analysis. 


\section{Analysis}

Muscle samples were partially thawed at $4{ }^{\circ} \mathrm{C}$ and trimmed to remove residual adipose tissue and the epimysium. Total meat lipids were extracted by means of a chloroform/methanol solution (2:1, v/v), according to Rodriguez-Estrada, Penazzi, Caboni, Bertacco, and Lercker (1997).

Milk fat extraction was performed according to the Rose-Gottlieb Method (1990) modified by Secchiari et al. (2003a). Briefly, ammonia 25\% (0.4 mL), ethyl alcohol 95\% (1 mL) and hexane $(5 \mathrm{~mL})$ were added to $2 \mathrm{~g}$ of a raw milk sample. After being vortexed, the samples were centrifuged at $3,000 \mathrm{rpm}$ and $2{ }^{\circ} \mathrm{C}$. After phase's separation, the upper layer was collected. The extraction was repeated a second time using ethyl alcohol 95\% (1 mL) and hexane $(5 \mathrm{~mL})$; the samples were centrifuged at $3000 \mathrm{rpm}$ and the upper layer was collected. After a third extraction using $5 \mathrm{~mL}$ of hexane, the samples were centrifuged at $3,000 \mathrm{rpm}$ and the upper layer was collected. The extracted fat was dried at $35^{\circ} \mathrm{C}$ by means of a rotary evaporator, weighed and finally dissolved in hexane.

An aliquot of milk and muscle lipids was used in order to obtain fatty acid methyl esters: $10 \mathrm{mg}$ of total lipids were added with $0.5 \mathrm{mg}$ of nonadecanoic acid (C19:0) methyl ester (Sigma Chemical Co., St. Louis, MO, USA) as the internal standard, and then transesterified by cool base catalysed trans-esterification by using $0.5 \mathrm{~N}$ methanolic solution of sodium methoxide according to Christie's procedure (1982). The transmethylation was achieved in 5 min at room temperature.

Fatty acid methyl esters were identified and quantified by gas chromatography using a ThermoQuest (Milan, Italy) gas-chromatograph apparatus equipped with an FID and a high polar fused silica capillary column (Chrompack CP-Sil 88 Varian, Middelburg, Netherland; $100 \mathrm{~m} \times 0.25 \mathrm{~mm}$ i.d.; film thickness $0.20 \mu \mathrm{m}$ ). Helium was used as the carrier gas at a flow of $1 \mathrm{~mL} / \mathrm{min}$. The split ratio was $1: 100$. One $\mu \mathrm{L}$ of the sample was injected under the following GC conditions: the oven temperature was programmed at $120{ }^{\circ} \mathrm{C}$ and held for $1 \mathrm{~min}$, then increased to $180^{\circ} \mathrm{C}$ at a rate of $5{ }^{\circ} \mathrm{C} / \mathrm{min}$, held for $18 \mathrm{~min}$, increased to $200{ }^{\circ} \mathrm{C}$ at $2{ }^{\circ} \mathrm{C} / \mathrm{min}$, held for $1 \mathrm{~min}$, increased to $230{ }^{\circ} \mathrm{C}$ at a rate of $2{ }^{\circ} \mathrm{C} / \mathrm{min}$ and held for 19 min. The injector temperature was set at $270{ }^{\circ} \mathrm{C}$, whereas the detector temperature at $300{ }^{\circ} \mathrm{C}$.

Individual FAMEs were identified by comparison to a standards mixture of 37 Component FAME Mix (Supelco, Bellefonte PA, USA). The identification of isomers of C18:1 was based on commercial standard mixtures (Supelco, Bellefonte PA, USA) and published 
isomeric profiles (Wolf \& Bayard, 1995). All methods using peak normalisation and which express the results in relative percentages of the area of the analysed peaks are subject to overestimation because the areas of small peaks are not considered. To avoid this problem, nonadecanoic acid as the internal standard was used and all the results concerning the milk and meat fatty acid composition were expressed as $\mathrm{g} / 100 \mathrm{~g}$ of total fat. Conjugated Linoleic Acid (CLA) isomers were separated and quantified by a silver ion HPLC column (Chromsphere 5 Lipids, Varian, Middelburg, Netherlands; $250 \mathrm{~mm} \times 4.6 \mathrm{~mm}$ i.d.) using the procedure reported in Sehat et al. (1998). CLA isomers were eluted using a fresh mixture of acetonitrile $0.1 \%(\mathrm{v} / \mathrm{v})$ in hexane at a flow of $1 \mathrm{~mL} / \mathrm{min}$. The injection loop was $20 \mu 1$ and UV detection was performed at a wavelength of $233 \mathrm{~nm}$. Since a reliable internal standard for CLA is not yet available, the quantitative measurements were performed through a calibration curve, using high purity individual cis-9, trans-11 and trans-10, cis12 CLA (Matreya Inc., Pleasant Gap PA, USA). CLA mix standard (Sigma Chemical Co., St. Louis, MO, USA), and published isomeric profile (Kramer et al., 2004) were also used to help identify the CLA isomers in ovine milk and meat.

FAs of meat and milk were expressed as $\mathrm{g} / 100 \mathrm{~g}$ of total lipids, whereas CLA isomers were expressed as $\mathrm{mg} / 100 \mathrm{~g}$ of total lipid.

\section{Statistical analysis}

Data on meat fatty acid composition were processed separately for each muscle by the GLM procedure of SAS (1999), using a linear model that included the live slaughter weight and residual error. Least square means were compared by the predicted difference method with Tukey adjustment test (SAS, 1999).

In order to evaluate temporal changes of the maternal milk fatty acid composition, data were grouped according to five classes of days in milk (DIM). The first class included milk samples collected during the first five days from lambing ( $\mathrm{DIM}_{1}$, the colostrum phase). The second to fifth classes $\left(\mathrm{DIM}_{2}-\mathrm{DIM}_{5}\right)$ included milk samples collected from 6 to 11,12 to 17,18 to 23 , and 24 to 29 DIM, respectively. Milk data were processed by the mixed procedure of SAS (1999) using the following linear model

$y_{j n}=m+\mathrm{DIM}_{j}+L_{n}+e_{j n}$

Where $y$ is the value of individual milk fatty acids of lactation $n, m$ the overall mean, DIM the fixed effect of the days in milking interval $(j=1,2 \ldots 5), L$ is the random effect of each individual lactation, and $e$ the residual error. 


\section{Results and discussion}

Table 1, Table 2 and Table 3 show CLA isomers content of Longissimus dorsi (LD),

Triceps brachii (TB), and Semimembranosus (Sm) muscles from lambs slaughtered at 11, 14 and $17 \mathrm{~kg}$ live weight.

Table 1. CLA isomers of meat from Longissimus dorsi muscle in lambs slaughtered at 11,14 and $17 \mathrm{~kg}$ of live weight $(\mathrm{mg} / 100 \mathrm{~g}$ of total lipids)

\begin{tabular}{|c|c|c|c|c|c|}
\hline \multicolumn{6}{|c|}{ Weight of slaughtering $(\mathrm{kg})$} \\
\hline Isomers & $\begin{array}{c}11 \\
n=6\end{array}$ & $\begin{array}{c}14 \\
n=6\end{array}$ & $\begin{array}{c}17 \\
n=6\end{array}$ & SE & $\mathrm{P}$ \\
\hline $12 / 14 t / t$ & 15.47 & 18.11 & 21.84 & 2.59 & 0.25 \\
\hline $11 / 13 t / t$ & 20.75 & 18.16 & 20.73 & 2.57 & 0.72 \\
\hline $10 / 12 t / t$ & 2.04 & 1.44 & 3.66 & 0.63 & 0.06 \\
\hline $9 / 11 t / t$ & 15.64 & 14.46 & 20.35 & 2.35 & 0.20 \\
\hline $7 / 9 t / t$ & 3.13 & 2.21 & 6.51 & 2.31 & 0.40 \\
\hline $13 / 15 \mathrm{c} / \mathrm{t}$ & 5.67 & 8.86 & 6.38 & 3.07 & 0.75 \\
\hline $12 / 14 c / t$ & 7.65 & 8.53 & 7.19 & 2.19 & 0.91 \\
\hline $11 / 13 t / c$ & 48.19 & 49.35 & 42.43 & 10.72 & 0.89 \\
\hline $11 / 13 \mathrm{c} / \mathrm{t}$ & 12.73 & 8.84 & 18.42 & 6.33 & 0.57 \\
\hline $9 / 11 \mathrm{c} / \mathrm{t}$ & 1238.11 & 1324.76 & 1478.98 & 124.88 & 0.41 \\
\hline $7 / 9 \mathrm{t} / \mathrm{c}$ & 30.17 & 35.03 & 44.32 & 4.68 & 0.13 \\
\hline $8 / 10 c / c$ & 3.96 & 3.48 & 5.80 & 1.07 & 0.29 \\
\hline Total $c / c$ & 9.74 & 10.58 & 11.73 & 2.53 & 0.86 \\
\hline Total $t / t$ & 62.45 & 57.14 & 78.57 & 8.05 & 0.18 \\
\hline Total $c / t$ or $t / c$ & 1350.26 & 1437.96 & 1597.72 & 136.19 & 0.45 \\
\hline Total CLA & 1422.97 & 1508.91 & 1689.87 & 138.82 & 0.40 \\
\hline $\begin{array}{l}\text { C18:2 } 13 / 15 t / t, \\
11 / 13 \mathrm{c} / \mathrm{c} \text { are dete }\end{array}$ & $12 t / t, C$ & $\begin{array}{l}t / t, \mathrm{C} 18 \\
\text { cause }<\end{array}$ & $\begin{array}{l}c / t, \mathrm{C} 18: \\
\text { g of tota }\end{array}$ & C18:2 10 & $\mathrm{C} 18: 2$ \\
\hline
\end{tabular}

Table 2. CLA isomers of meat from Triceps brachii muscle in lambs slaughtered at 11,14 and $17 \mathrm{~kg}$ of live weight $(\mathrm{mg} / 100 \mathrm{~g}$ of total lipids)

\begin{tabular}{|c|c|c|c|c|c|}
\hline \multicolumn{6}{|c|}{ Weight of slaughtering (kg) } \\
\hline Isomers & $\begin{array}{c}11 \\
n=6\end{array}$ & $\begin{array}{c}14 \\
n=6\end{array}$ & $\begin{array}{c}17 \\
n=6\end{array}$ & SE & $\mathrm{P}$ \\
\hline $12 / 14 \mathrm{t} / \mathrm{t}$ & 15.92 & 22.64 & 18.74 & 2.60 & 0.24 \\
\hline $11 / 13 \mathrm{t} / \mathrm{t}$ & 20.22 & 25.47 & 20.24 & 2.44 & 0.25 \\
\hline $10 / 12 \mathrm{t} / \mathrm{t}$ & 4.01 & 2.97 & 3.07 & 0.98 & 0.72 \\
\hline $9 / 11 \mathrm{t} / \mathrm{t}$ & 13.03 & 17.15 & 19.50 & 2.48 & 0.21 \\
\hline $7 / 9 \mathrm{t} / \mathrm{t}$ & $1.51^{\mathrm{a}}$ & $3.15^{\mathrm{b}}$ & $3.69^{\mathrm{b}}$ & 0.52 & 0.03 \\
\hline $13 / 15 \mathrm{c} / \mathrm{t}$ & 3.58 & 5.01 & 5.80 & 0.90 & 0.24 \\
\hline $12 / 14 \mathrm{c} / \mathrm{t}$ & 4.27 & 6.58 & 6.60 & 0.80 & 0.09 \\
\hline $11 / 13 \mathrm{t} / \mathrm{c}$ & 56.56 & 57.25 & 58.23 & 0.49 & 0.68 \\
\hline $11 / 13 \mathrm{c} / \mathrm{t}$ & 6.48 & 3.40 & 4.06 & 1.37 & 0.28 \\
\hline $9 / 11 \mathrm{c} / \mathrm{t}$ & $1240.21^{\mathrm{a}}$ & $1555.03^{\mathrm{a}}$ & $1686.52^{\mathrm{b}}$ & 118.49 & 0.05 \\
\hline $7 / 9 \mathrm{t} / \mathrm{c}$ & $31.70^{\mathrm{A}}$ & $37.74^{\mathrm{a}}$ & $61.48^{\mathrm{Bb}}$ & 6.50 & 0.01 \\
\hline $8 / 10 \mathrm{c} / \mathrm{c}$ & 2.57 & 3.27 & 4.60 & 0.66 & 0.12 \\
\hline Total c/c & 6.29 & 7.06 & 8.50 & 1.13 & 0.39 \\
\hline Total $\mathrm{t} / \mathrm{t}$ & 55.37 & 78.27 & 65.64 & 7.74 & 0.14 \\
\hline Total $\mathrm{c} / \mathrm{t}$ or $\mathrm{t} / \mathrm{c}$ & $1338.80^{\mathrm{a}}$ & $1668.45^{\mathrm{a}}$ & $1822.70^{\mathrm{b}}$ & 127.24 & 0.04 \\
\hline Total CLA & $1401.79^{\mathrm{a}}$ & $1756.08^{\mathrm{a}}$ & $1934.05^{\mathrm{b}}$ & 131.29 & 0.03 \\
\hline $\begin{array}{l}\text { C18:2 } 13 / 15 t / t, C \\
11 / 13 c / c \text { are dete } \\
\text { Least square mea } \\
\text { capital } \mathrm{p}<0.01 .\end{array}$ & $\begin{array}{l}0 / 12 t / t, \mathrm{C} \\
\mathrm{t} \text { are not re } \\
\text { he same ro }\end{array}$ & $\begin{array}{l}10 t / t, \mathrm{C} 18 \\
\text { oecause }< \\
\text { different }\end{array}$ & $\begin{array}{l}c / t, \mathrm{C} 18: 2 \\
0 \mathrm{~g} \text { of total } \\
\text { ipt letters }\end{array}$ & $\begin{array}{l}18: 210 / \\
\text { t: small }\end{array}$ & $\begin{array}{l}\text { C18:2 } \\
<0.05,\end{array}$ \\
\hline
\end{tabular}


Table 3. CLA isomers of meat from Semimembranosus muscle in lambs slaughtered at 11,14 and $17 \mathrm{~kg}$ of live weight (mg/100g of total lipids)

\begin{tabular}{|c|c|c|c|c|c|}
\hline \multicolumn{4}{|c|}{ Weight of slaughtering $(\mathrm{kg})$} & \multirow[b]{2}{*}{ SE } & \multirow[b]{2}{*}{$\mathrm{P}$} \\
\hline Isomers & $\begin{array}{c}11 \\
n=6\end{array}$ & $\begin{array}{c}14 \\
n=6\end{array}$ & $\begin{array}{c}17 \\
n=6\end{array}$ & & \\
\hline $12 / 14 t / t$ & 12.24 & 21.45 & 21.61 & 3.93 & 0.19 \\
\hline $11 / 13 t / t$ & 15.58 & 17.94 & 23.59 & 3.96 & 0.36 \\
\hline $10 / 12 t / t$ & 0.85 & 1.76 & 3.39 & 1.09 & 0.26 \\
\hline $9 / 11 t / t$ & 14.98 & 15.96 & 18.94 & 2.49 & 0.56 \\
\hline $7 / 9 t / t$ & 2.03 & 2.82 & 3.04 & 0.08 & 0.65 \\
\hline $13 / 15 \mathrm{c} / t$ & 9.01 & 4.41 & 7.10 & 2.17 & 0.35 \\
\hline $12 / 14 c / t$ & 8.21 & 5.48 & 9.09 & 2.10 & 0.47 \\
\hline $11 / 13 t / c$ & 52.01 & 48.28 & 63.10 & 8.71 & 0.47 \\
\hline $11 / 13 \mathrm{c} / \mathrm{t}$ & 5.82 & 6.23 & 5.03 & 0.96 & 0.68 \\
\hline $9 / 11 \mathrm{c} / \mathrm{t}$ & $1152.98^{\mathrm{A}}$ & $1357.16^{\mathrm{AB}}$ & $1639.49^{\mathrm{B}}$ & 103.16 & 0.01 \\
\hline $7 / 9 t / c$ & $28.71^{\mathrm{a}}$ & $36.16^{\mathrm{ab}}$ & $48.42^{\mathrm{b}}$ & 4.81 & 0.03 \\
\hline $8 / 10 c / c$ & $2.42^{\mathrm{A}}$ & $4.18^{\mathrm{A}}$ & $6.20^{\mathrm{B}}$ & 0.80 & 0.02 \\
\hline Total $c / c$ & 6.95 & 4.09 & 8.08 & 1.45 & 0.19 \\
\hline Total $t / t$ & 48.16 & 64.71 & 76.07 & 10.84 & 0.25 \\
\hline Total $c / t$ or $t / c$ & $1285.43^{\mathrm{A}}$ & $1472.34^{\mathrm{AB}}$ & $1775.40^{\mathrm{B}}$ & 108.49 & 0.01 \\
\hline Total CLA & 1313.55 & 1541.14 & 1876.11 & 115.29 & 0.01 \\
\hline \multicolumn{6}{|c|}{$\begin{array}{l}\mathrm{C} 18: 213 / 15 \mathrm{t} / \mathrm{t}, \mathrm{C} 18: 210 / 12 \mathrm{t} / \mathrm{t}, \mathrm{C} 18: 28 / 10 \mathrm{t} / \mathrm{t}, \mathrm{C} 18: 28 / 10 \mathrm{c} / \mathrm{t}, \mathrm{C} 18: 29 / 11 \mathrm{c} / \mathrm{c}, \mathrm{C} 18: 210 / 12 \mathrm{c} / \mathrm{c} \text { and } \mathrm{C} 18: 2 \\
11 / 13 \mathrm{c} / \mathrm{c} \text { are detected but are not reported because }<5 \mathrm{mg} / 100 \mathrm{~g} \text { of total lipids } \\
\text { Least square means in the same row with different superscript letters are different: small } 0.01<\mathrm{p}<0.05 \text {, } \\
\text { capital } \mathrm{p}<0.01 .\end{array}$} \\
\hline
\end{tabular}

In each case RA was higher than $87 \%$ of total CLA isomers. Slaughter weight affected RA content in the intramuscular fat only in TB and Sm, being lower in youngest carcasses, but not in LD. Likewise, in TB and Sm, but not in LD, the intramuscular fats content of trans7, cis-9 18:2 (the third major CLA isomer, 2.5\% of total CLA isomers) increased with the slaughter age. Like RA, trans-7, cis-9 18:2 may originate by stearoyl Co-A desaturase activity. Therefore its content in muscle fat may be considered another indirect indicator of activity of this enzyme.

Minor CLA isomers such as trans-7, trans-9 18:2 in TB and cis-8, cis-10 18:2 in Sm, increased with the age of animals. Finally, also total cis/trans or trans/cis CLA and total CLA were lower in TB and Sm from youngest carcasses, but not in LD. In this study the trans-10, cis-12 18:2 CLA isomer was not detected.

In our experiment the content of total CLA in lamb meat was two-three fold higher than that reported in the literature for heavier lambs that were fed pasture and/or oilseeds (Demirel et al., 2004, Diaz et al., 2005, Maranesi et al., 2005 and Santos-Silva et al., 2003) and similar to that reported by (Lanza et al., 2006a) and (Lanza et al., 2006b) and Valvo et al. (2005) in lambs that were fed only maternal milk. 
Since the fatty acid composition of muscle from pre-weaning lambs generally reflects the fatty acid composition of the suckled milk (Bas \& Morand-Fehr, 2000), the high value of CLA in lamb muscle found in our study may be due to the fact that the lambs suckled milk from grazing ewes. The CLA milk content, in fact, dramatically varies according to dietary regimen of lactating ewes being higher when sheep are feed pasture or unsaturated oil. Moreover the nature and maturity of pasture may significantly affect the level of CLA in milk. As a general effect, during spring and fall, the level of CLA in milk is higher than in summer (Banni et al., 1996, Secchiari et al., 2001 and Tsiplakou et al., 2006). This trend is related to the environment of Mediterranean areas, where the green forages are present principally in spring and in fall. This study was carried out during spring and CLA milk content varied from $2.3 \mathrm{~g} / 100 \mathrm{~g}$ to $2.9 \mathrm{~g} / 100 \mathrm{~g}$ of muscle fat. These values are similar to that reported in literature for milk from grazing ewes in spring season (Banni et al., 1996, Secchiari et al., 2001, Tsiplakou et al., 2006 and Valvo et al., 2005).

In order to verify how changes in milk fatty acid composition during the suckling period affected the fatty acid composition of muscle from suckling lambs, we reported the fatty acid composition of milk from the lamb's mothers, during the first five weeks of lactation Table 4 and Table 6. CLA content was higher in colostrum (DIM $)$, subsequently decreased and then increased at the last control ( $\mathrm{DIM}_{5}, p=0.07$ and $p=0.02$ for total CLA and RA milk content, respectively), when ewes were more than 28 days in lactation (Table 4). High RA value of $\mathrm{DIM}_{5}$ is probably due to the effect of lactation. As reported in dairy cows (Kelsey et al., 2003 and Secchiari et al., 2003b), in fact, the CLA content in milk tends to increase during the first month of lactation and afterwards to decrease. Anyway, fatty acid composition of milk suckled by lambs slaughtered at 11 and $14 \mathrm{~kg}$ was different to that of milk suckled by lambs slaughtered at $17 \mathrm{~kg}$. Since heavier lambs were suckled milk with the highest levels of RA and total CLA and for a longer time, it is not possible to exclude a tissue accumulation effect. As a consequence, meat RA content rose with the increase in age of slaughter but only in TB and Sm (Table 1, Table 2 and Table 3).

Likewise in muscle fat, the trans-10, cis-12 18:2 isomer was not detected in milk. This CLA isomer originates mainly from a "shift" of the rumen bio-hydrogenation process of dietary linoleic acid, when animals are fed diet with high concentrate/forage ratio (Bauman \& Griinari, 2000). In this study the ewes were fed only pasture, rich in $\alpha$-linolenic acid that, during bio-hydrogenation, produces as main intermediates a non conjugated dienes (trans-11, cis-15 18:2), VA and others C18:1 isomers. 
RA may also originate from endogenous synthesis by way of the stearoyl Co-A desaturase (SCD) enzyme, which is able to insert a double bound in the cis-9 position in a large spectrum of fatty acids, including VA. The level of the SCD expression was tested in lactating and growing cattle (Delbecchi et al., 2001, Griinari et al., 2000 and Taniguchi et al., 2004), but little is known about the SCD activity in pre-weaning lambs.

Table 4. CLA isomers of sheep milk (mg/100g of total lipids).

\begin{tabular}{|c|c|c|c|c|c|c|}
\hline Isomers & $\begin{array}{c}\mathrm{DIM}_{1} \\
\mathrm{n}=18\end{array}$ & $\begin{array}{l}\mathrm{DIM}_{2} \\
\mathrm{n}=18\end{array}$ & $\begin{array}{l}\mathrm{DIM}_{3} \\
\mathrm{n}=14\end{array}$ & $\begin{array}{l}\mathrm{DIM}_{4} \\
\mathrm{n}=12\end{array}$ & $\begin{array}{c}\mathrm{DIM}_{5} \\
\mathrm{n}=6\end{array}$ & $P$ value \\
\hline $12 / 14 t / t$ & $51.04 \pm 3.60$ & $52.09 \pm 3.61$ & $44.99 \pm 4.10$ & $46.46 \pm 4.30$ & $37.52 \pm 8.21$ & 0.40 \\
\hline $11 / 13 t / t$ & $63.17 \pm 3.85$ & $68.96 \pm 3.86$ & $67.52 \pm 4.38$ & $73.62 \pm 4.60$ & $64.18 \pm 8.76$ & 0.50 \\
\hline $10 / 12 t / t$ & $6.35 \pm 4.60$ & $6.15 \pm 4.61$ & $6.94 \pm 5.24$ & $17.45 \pm 5.50$ & $13.79 \pm 10.48$ & 0.50 \\
\hline $9 / 11 t / t$ & $32.04 \pm 4.12$ & $30.47 \pm 4.14$ & $34.99 \pm 4.70$ & $35.60 \pm 4.93$ & $38.94 \pm 9.39$ & 0.87 \\
\hline $8 / 10 t / t$ & $5.19^{\mathrm{a}} \pm 0.86$ & $6.66^{\mathrm{ab}} \pm 0.86$ & $7.90^{\mathrm{bc}} \pm 0.98$ & $6.24^{\mathrm{a}} \pm 1.03$ & $11.84^{\mathrm{c}} \pm 1.97$ & 0.03 \\
\hline $7 / 9 t / t$ & $4.90 \pm 0.83$ & $5.50 \pm 0.83$ & $4.56 \pm 0.94$ & $4.23 \pm 0.99$ & $7.90 \pm 1.89$ & 0.47 \\
\hline $13 / 15 \mathrm{c} / t$ & $6.17^{\mathrm{a}} \pm 0.55$ & $4.21^{\mathrm{b}} \pm 0.55$ & $4.14^{\mathrm{b}} \pm 0.62$ & $3.74^{\mathrm{b}} \pm 0.65$ & $8.70^{\mathrm{a}} \pm 1.25$ & $<0.01$ \\
\hline $12 / 14 c / t$ & $19.19 \pm 1.51$ & $18.83 \pm 1.51$ & $14.55 \pm 1.72$ & $15.08 \pm 1.80$ & $17.47 \pm 3.43$ & 0.18 \\
\hline $11 / 13 c / t$ & $16.75 \pm 4.78$ & $25.10 \pm 4.80$ & $20.63 \pm 5.45$ & $14.65 \pm 5.72$ & $18.95 \pm 10.89$ & 0.64 \\
\hline $11 / 13 \mathrm{t} / \mathrm{c}$ & $0.10 \pm 0.01$ & $0.10 \pm 0.01$ & $0.10 \pm 0.01$ & $0.11 \pm 0.01$ & $0.12 \pm 0.02$ & 0.49 \\
\hline $9 / 11 \mathrm{c} / t$ & $2465.92^{\mathrm{a}} \pm 91.04$ & $2037.88^{\mathrm{b}} \pm 91.38$ & $1965.07^{b} \pm 103.73$ & $2038.77^{b} \pm 108.91$ & $2487.44^{\mathrm{a}} \pm 207.39$ & $<0.01$ \\
\hline $7 / 9 t / c$ & $69.19 \pm 5.52$ & $64.76 \pm 5.54$ & $64.06 \pm 6.28$ & $71.81 \pm 6.60$ & $78.31 \pm 12.57$ & 0.77 \\
\hline $11 / 13 c / c$ & $7.65^{\mathrm{a}} \pm 2.97$ & $6.11^{\mathrm{a}} \pm 2.98$ & $14.85^{\mathrm{a}} \pm 3.39$ & $6.54^{\mathrm{a}} \pm 3.56$ & $29.00^{\mathrm{b}} \pm 6.77$ & 0.02 \\
\hline Total CLA $t / t$ & $166.85 \pm 9.95$ & $173.42 \pm 9.99$ & $170.97 \pm 11.34$ & $186.55 \pm 11.91$ & $178.01 \pm 22.67$ & 0.79 \\
\hline Total CLA $c / t$ or $t / c$ & $2679.65^{\mathrm{a}} \pm 95.32$ & $2248.29^{\mathrm{b}} \pm 95.68$ & $2173.18^{\mathrm{b}} \pm 108.86$ & $2257.37^{\mathrm{b}} \pm 114.04$ & $2735.89^{\mathrm{a}} \pm 217.16$ & $<0.01$ \\
\hline Total CLA $c / c$ & $13.34 \pm 6.60$ & $10.63 \pm 6.62$ & $33.20 \pm 7.51$ & $15.99 \pm 7.89$ & $40.50 \pm 15.02$ & 0.10 \\
\hline Total CLA & $2836.28^{\mathrm{a}} \pm 97.56$ & $2455.86^{\mathrm{b}} \pm 98.92$ & $2355.56^{\mathrm{b}} \pm 108.58$ & $2492.27^{b} \pm 116.53$ & $2962.64 \pm 222.17^{\mathrm{a}}$ & $<0.01$ \\
\hline
\end{tabular}

C18:2 13/15 t/t, C18:2 6/8 t/t, C18:2 8/10 c/c, C18:2 9/11 c/c and C18:2 10/12 c/c are detected but are not reported because their quantity is $<5 \mathrm{mg} / 100 \mathrm{~g}$ of total lipids.

DIM, days in milk, where: $\mathrm{DIM}_{1}$ (colostrum) milk sampled within 5 days from lambing; $\mathrm{DIM}_{2} ;$ milk sampled from 6 to 12 days in milk; $\mathrm{DIM}_{3}$, milk sampled from 12 to 17 days in milk; DIM , milk sampled from 18 to 23 days in milk; DIM $_{5}$, milk sampled from 24 to 29 days in milk.

CLA, Conjugated Linoleic Acid

Least square means in the same row with different superscript letters are different $\mathrm{P}<0.05$.

SCD activity may be determined by tissue sampling, but this method is very expensive and invasive. Alternatively, SCD activity can be estimated by using convenient product/substrate ratios calculated as follows: product of $\Delta 9$ desaturase/(product of $\Delta 9$ desaturase + substrate of $\Delta 9$ desaturase) (Malau-Aduli, Siebert, Bottema, \& Pitchford, 1998). This formula may be applied to four product/substrate pairs: $C_{14: 1} / C_{14: 0} ; C_{16: 1} / C_{16: 0}$; $\mathrm{C}_{18: 1 \text { cis }} / \mathrm{C}_{18: 0}$ and $\mathrm{RA} / \mathrm{VA}$. The most efficient indicator seems to be the $\mathrm{C}_{14: 1} / \mathrm{C}_{14: 0}$ ratio, because $\mathrm{C}_{14: 0}$ in milk fat originates almost exclusively from de novo synthesis within the mammary gland and as a consequence, almost all the myristoleic acid present in the milk is likely to be synthesised in the mammary gland by SCD (Bernard, Leroux, \& Chilliard, 2006). Palmquist, St-Pierre, and McClure (2004) recently proposed that the $C_{14: 1} / C_{14: 0}$ ratio can be used to quantify endogenous RA synthesis also in lambs.

The slaughtering weight was not a significant variation factor for the $C_{16: 1} / C_{16: 0}$ and $\mathrm{C}_{18: 1 c i s} / \mathrm{C}_{18: 0}$ ratios in all muscles (Table 5a, Table $5 \mathrm{~b}$ and Table $5 \mathrm{c}$ ). On the contrary, the 
myristoleic/myristic acid ratio increased with the slaughter weight (Table 5a, Table 5b and Table 5c). On the basis of $\mathrm{C}_{14: 1} / \mathrm{C}_{14: 0}$ ratio, $\mathrm{SCD}$ activity seemed to increase in all muscles with slaughter weight. This effect did not seem related to the milk content of $\mathrm{C}_{14: 0}$ and $\mathrm{C}_{14: 1}$, because the content of these fatty acids in milk (Table 4) and their ratio tended to decrease with lactation $\left(\mathrm{TD}_{1}=0.017, \mathrm{TD}_{5}=0.007 ; p=0.22\right)$.

Table 5a. Desaturation indexes of miristic acid, palmitic acid, and stearic acid of meat from in Longissimus dorsi, muscle of lambs slaughtered at 11,14 and $17 \mathrm{~kg}$ of live weight.

\begin{tabular}{|c|c|c|c|c|c|}
\hline \multicolumn{4}{|c|}{ Weight of slaughtering (kg) } & \multirow[b]{2}{*}{ SE } & \multirow[b]{2}{*}{$\mathrm{P}$} \\
\hline & $\begin{array}{c}11 \\
\mathrm{n}=6\end{array}$ & $\begin{array}{c}14 \\
n=6\end{array}$ & $\begin{array}{c}17 \\
\mathrm{n}=6\end{array}$ & & \\
\hline DI C14:0 & $3.17^{\mathrm{A}}$ & $4.39^{\mathrm{B}}$ & $4.33^{\mathrm{B}}$ & 0.25 & $<0.01$ \\
\hline DI C16:0 & $7.22^{\mathrm{a}}$ & $10.06^{\mathrm{b}}$ & $9.45^{\mathrm{b}}$ & 0.71 & 0.03 \\
\hline DI C18:0 & 72.34 & 74.26 & 73.21 & 0.73 & 0.18 \\
\hline
\end{tabular}

DI C14:0, Desaturation Index of miristic acid, C14:1 / (C14:0 + C14:1) $\times 100$

DI C16:0, Desaturation Index of palmitic acid, C16:1 / (C16:0 + C16:1) $\times 100$.

DI C18:0, Desaturation Index of stearic acid, C18:1 cis9 / (C18:0 + C18:1 cis 9) $\times 100$.

Least square means in the same row with different superscript letters are different: small $0.01<\mathrm{p}<0.05$, capital $\mathrm{p}<0.01$.

Table 5b. Desaturation indexes of miristic acid, palmitic acid, and stearic acid of meat from in Semimembranosus muscle of lambs slaughtered at 11,14 and $17 \mathrm{~kg}$ of live weight.

\begin{tabular}{|c|c|c|c|c|c|}
\hline \multicolumn{4}{|c|}{ Weight of slaughtering (kg) } & \multirow[b]{2}{*}{ SE } & \multirow[b]{2}{*}{$\mathrm{P}$} \\
\hline & $\begin{array}{c}11 \\
\mathrm{n}=6\end{array}$ & $\begin{array}{c}14 \\
\mathrm{n}=6\end{array}$ & $\begin{array}{c}17 \\
n=6\end{array}$ & & \\
\hline DI C14:0 & 3.51 & 4.06 & 4.49 & 0.35 & 0.17 \\
\hline DI C16:0 & 4.69 & 6.77 & 5.76 & 1.10 & 0.43 \\
\hline DI C18:0 & 75.15 & 75.06 & 75.15 & 1.82 & 0.99 \\
\hline $\begin{array}{l}\text { DI C14:0, D } \\
\text { DI C16:0, D } \\
\text { DI C18:0, D }\end{array}$ & $\begin{array}{l}\text { idex of } \\
\text { adex of } \\
\text { adex of }\end{array}$ & $\begin{array}{l}: 1 /(\mathrm{C} \\
6: 1 /(\mathrm{C} \\
1 \text { cis } 9\end{array}$ & $\begin{array}{l}00 . \\
100 . \\
\operatorname{cis} 9)>\end{array}$ & & \\
\hline
\end{tabular}

Table 5c. Desaturation indexes of miristic acid, palmitic acid, and stearic acid of meat from in Triceps brachii muscle of lambs slaughtered at 11,14 and $17 \mathrm{~kg}$ of live weight.

\begin{tabular}{ccccccc}
\hline & \multicolumn{3}{c}{ Weight of slaughtering $(\mathrm{kg})$} & & \\
& 11 & 14 & 17 & & \\
& $\mathrm{n}=6$ & $\mathrm{n}=6$ & $\mathrm{n}=6$ & & & $\mathrm{P}$ \\
\hline DI C14:0 & $3.36^{\mathrm{a}}$ & $4.29^{\mathrm{b}}$ & $4.47^{\mathrm{b}}$ & & 0.28 & 0.04 \\
DI C16:0 & 6.73 & 5.00 & 5.41 & & 0.78 & 0.57 \\
DI C18:0 & 72.69 & 73.50 & 73.83 & & 0.58 & 0.39 \\
\hline
\end{tabular}

DI C14:0, Desaturation Index of miristic acid, C14:1 / (C14:0 + C14:1) $\times 100$.

DI C16:0, Desaturation Index of palmitic acid, C16:1 / (C16:0 + C16:1) $\times 100$.

DI C18:0, Desaturation Index of stearic acid, C18:1 cis $9 /(\mathrm{C} 18: 0+\mathrm{C} 18: 1$ cis 9$) \times 100$.

Least square means in the same row with different superscript letters are different $p<0.05$

This fact, together with the lower RA intake in the diet, may explain the lower RA content in TB and Sm muscles from animals slaughtered at a live weight of $11 \mathrm{~kg}$ (Table 2 and Table 3). 
The close linear relationship between VA and RA reported in literature (Baumann et al., 2006) was also confirmed in our study (Fig. 1). Differences between the regressions coefficients at the three slaughtering weight for each muscle were not significant, indicating a similar SCD capacity across slaughter ages.

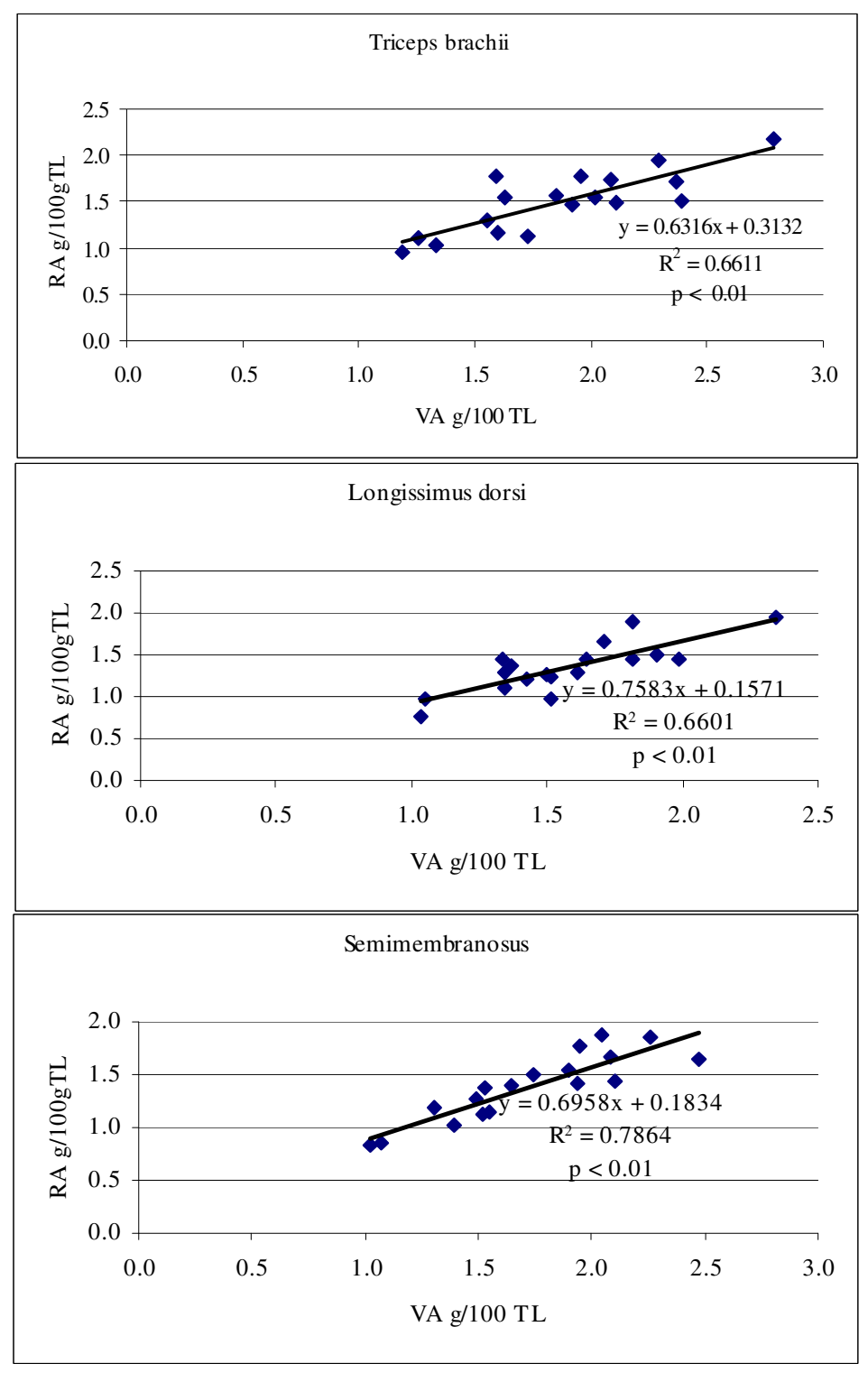

Figure 1. Relationship between trans-11 18:1 (VA) and cis-9, trans-11 18:2 (RA) in meat from Triceps brachii, Longissimus dorsi and Semimembranosus muscles (Each point report a pool of carcasses from animals slaughtered at 11,14 and $17 \mathrm{~kg}$ because were not differences among slaughtering age in proportions of fatty acids). 


\begin{tabular}{|c|c|c|c|c|c|c|}
\hline Fatty acids & $\begin{array}{c}\mathrm{DIM}_{1} \\
\mathrm{n}=18\end{array}$ & $\begin{array}{l}\mathrm{DIM}_{2} \\
\mathrm{n}=18\end{array}$ & $\begin{array}{l}\mathrm{DIM}_{3} \\
\mathrm{n}=14\end{array}$ & $\begin{array}{l}\mathrm{DIM}_{4} \\
\mathrm{n}=12\end{array}$ & $\begin{array}{c}\mathrm{DIM}_{5} \\
\mathrm{n}=6\end{array}$ & $\mathrm{P}$ value \\
\hline C8:0-C12:0 & $5.63 \pm 0.35$ & $6.41 \pm 0.35$ & $6.63 \pm 0.39$ & $6.17 \pm 0.42$ & $4.34 \pm 0.80$ & 0.07 \\
\hline C14-iso & $0.07^{\mathrm{A}} \pm 0.01$ & $0.07 \pm 0.01^{\mathrm{Aa}}$ & $0.08 \pm 0.01^{\mathrm{Ab}}$ & $0.09 \pm 0.01^{\mathrm{Bc}}$ & $0.07 \pm 0.01^{\mathrm{A}}$ & $<0.01$ \\
\hline C14:0 & $6.93 \pm 0.26$ & $6.96 \pm 0.26$ & $6.84 \pm 0.28$ & $5.99 \pm 0.31$ & $5.84 \pm 0.58$ & 0.07 \\
\hline $\mathrm{C} 14: 1$ & $0.14 \pm 0.02$ & $0.10 \pm 0.02$ & $0.07 \pm 0.02$ & $0.06 \pm 0.02$ & $0.03 \pm 0.05$ & 0.11 \\
\hline C15-anteiso & $0.37 \pm 0.02$ & $0.38 \pm 0.02$ & $0.41 \pm 0.02$ & $0.42 \pm 0.02$ & $0.30 \pm 0.04$ & 0.06 \\
\hline $\mathrm{C} 15: 0$ & $0.79 \pm 0.04$ & $0.79 \pm 0.04$ & $0.78 \pm 0.04$ & $0.80 \pm 0.04$ & $0.66 \pm 0.08$ & 0.66 \\
\hline C16-iso & $0.17 \pm 0.01$ & $0.18 \pm 0.01$ & $0.19 \pm 0.01$ & $0.20 \pm 0.01$ & $0.15 \pm 0.02$ & 0.11 \\
\hline C16:0 & $18.72 \pm 0.43$ & $17.96 \pm 0.43$ & $18.11 \pm 0.47$ & $16.77 \pm 0.51$ & $17.69 \pm 0.97$ & 0.09 \\
\hline $\mathrm{C} 16: 1 \mathrm{n} 7$ & $0.64^{\mathrm{ac}} \pm 0.05$ & $0.48^{\mathrm{bc}} \pm 0.05$ & $0.42^{\mathrm{bc}} \pm 0.05$ & $0.45^{\mathrm{bc}} \pm 0.06$ & $0.59^{\mathrm{c}} \pm 0.11$ & 0.04 \\
\hline C17-anteiso & $0.42 \pm 0.02$ & $0.40 \pm 0.02$ & $0.41 \pm 0.02$ & $0.44 \pm 0.02$ & $0.43 \pm 0.04$ & 0.73 \\
\hline $\mathrm{C} 17: 0$ & $0.78 \pm 0.02$ & $0.81 \pm 0.02$ & $0.78 \pm 0.02$ & $0.86 \pm 0.02$ & $0.87 \pm 0.05$ & 0.10 \\
\hline C18:0 & $8.36 \pm 0.44$ & $9.63 \pm 0.44$ & $9.47 \pm 0.49$ & $9.45 \pm 0.53$ & $9.75 \pm 1.01$ & 0.28 \\
\hline C18:1 cis 9 & $17.18^{\mathrm{a}} \pm 0.58$ & $16.91^{\mathrm{a}} \pm 0.58$ & $15.96^{\mathrm{a}} \pm 0.64$ & $17.70^{\mathrm{a}} \pm 0.69$ & $21.17^{\mathrm{b}} \pm 1.32$ & 0.02 \\
\hline Others cis C18:1 & $0.75 \pm 0.04$ & $0.87 \pm 0.04$ & $0.77 \pm 0.04$ & $0.92 \pm 0.04$ & $0.84 \pm 0.08$ & 0.03 \\
\hline $\mathrm{C} 18: 1$ trans 11 & $3.18 \pm 0.17$ & $3.12 \pm 0.17$ & $2.88 \pm 0.18$ & $2.84 \pm 0.20$ & $2.97 \pm 0.38$ & 0.61 \\
\hline Other trans $\mathrm{C} 18: 1$ & $0.54 \pm 0.01$ & $0.52 \pm 0.01$ & $0.48 \pm 0.02$ & $0.53 \pm 0.02$ & $0.52 \pm 0.03$ & 0.08 \\
\hline $\mathrm{C} 18: 2 \mathrm{n} 6$ & $1.01^{\mathrm{a}} \pm 0.03$ & $0.94^{\mathrm{a}} \pm 0.03$ & $1.02^{\mathrm{a}} \pm 0.03$ & $1.13^{\mathrm{b}} \pm 0.03$ & $1.18^{\mathrm{b}} \pm 0.07$ & $<0.01$ \\
\hline $\mathrm{C} 18: 3 \mathrm{n} 3$ & $0.82^{\mathrm{ac}} \pm 0.02$ & $0.79^{\mathrm{a}} \pm 0.02$ & $0.88^{\mathrm{c}} \pm 0.03$ & $0.95^{\mathrm{bc}} \pm 0.03$ & $0.93^{\mathrm{bc}} \pm 0.05$ & $<0.01$ \\
\hline $\mathrm{C} 18: 4 \mathrm{n} 3$ & $0.08 \pm 0.01$ & $0.08 \pm 0.01$ & $0.07 \pm 0.01$ & $0.08 \pm 0.01$ & $0.08 \pm 0.01$ & 0.58 \\
\hline $\mathrm{C} 20: 0$ & $0.15 \pm 0.01$ & $0.17 \pm 0.01$ & $0.18 \pm 0.01$ & $0.18 \pm 0.01$ & $0.14 \pm 0.02$ & 0.16 \\
\hline C20:1 & $0.05 \pm 0.01$ & $0.05 \pm 0.01$ & $0.06 \pm 0.01$ & $0.06 \pm 0.01$ & $0.05 \pm 0.01$ & 0.61 \\
\hline C21:0 & $0.05^{\mathrm{aA}} \pm 0.01$ & $0.06^{\mathrm{aA}} \pm 0.01$ & $0.06^{\mathrm{a}} \pm 0.01$ & $0.07^{\mathrm{B}} \pm 0.01$ & $0.05^{\mathrm{a}} \pm 0.09$ & $<0.01$ \\
\hline $\mathrm{C} 22: 0$ & $0.15 \pm 0.01$ & $0.17 \pm 0.01$ & $0.18 \pm 0.01$ & $0.18 \pm 0.01$ & $0.14 \pm 0.02$ & 0.15 \\
\hline C20:4 n6 & $0.06 \pm 0.01$ & $0.07 \pm 0.01$ & $0.07 \pm 0.01$ & $0.05 \pm 0.01$ & $0.07 \pm 0.01$ & 0.07 \\
\hline $\mathrm{C} 20: 5 \mathrm{n} 3$ & $0.10 \pm 0.01$ & $0.10 \pm 0.01$ & $0.10 \pm 0.01$ & $0.09 \pm 0.01$ & $0.06 \pm 0.02$ & 0.45 \\
\hline $\mathrm{C} 24: 0$ & $0.04 \pm 0.01$ & $0.04 \pm 0.01$ & $0.05 \pm 0.01$ & $0.05 \pm 0.01$ & $0.04 \pm 0.01$ & 0.12 \\
\hline $\mathrm{C} 22: 5 \mathrm{n} 3$ & $0.13^{\mathrm{a}} \pm 0.01$ & $0.14^{\mathrm{a}} \pm 0.01$ & $0.12^{\mathrm{ab}} \pm 0.01$ & $0.11^{\mathrm{b}} \pm 0.01$ & $0.11^{\mathrm{b}} \pm 0.01$ & 0.03 \\
\hline $\mathrm{C} 22: 6 \mathrm{n} 3$ & $0.05^{\mathrm{ac}} \pm 0.01$ & $0.06^{\mathrm{Ab}} \pm 0.01$ & $0.05^{\mathrm{c}} \pm 0.01$ & $0.04^{\mathrm{Bb}} \pm 0.01$ & $0.04^{\mathrm{Bb}} \pm 0.01$ & $<0.01$ \\
\hline SFA & $44.00 \pm 0.85$ & $45.47 \pm 0.85$ & $45.55 \pm 0.94$ & $43.15 \pm 1.01$ & $41.99 \pm 1.93$ & 0.19 \\
\hline MUFA & $23.16^{\mathrm{a}} \pm 0.60$ & $22.68^{\mathrm{a}} \pm 0.60$ & $21.28^{\mathrm{bA}} \pm 0.66$ & $23.69^{\mathrm{a}} \pm 0.71$ & $26.90^{\mathrm{bB}} \pm 1.36$ & $<0.01$ \\
\hline PUFA n6 & $1.07^{\mathrm{a}} \pm 0.03$ & $1.02^{\mathrm{aA}} \pm 0.03$ & $1.10^{\mathrm{ac}} \pm 0.04$ & $1.19^{\mathrm{bc}} \pm 0.04$ & $1.26^{\mathrm{bBc}} \pm 0.08$ & $<0.01$ \\
\hline PUFA n3 & $1.19 \pm 0.03$ & $1.18 \pm 0.03$ & $1.23 \pm 0.03$ & $1.27 \pm 0.04$ & $1.23 \pm 0.07$ & 0.37 \\
\hline BCFA & $1.02 \pm 0.04$ & $1.03 \pm 0.04$ & $1.09 \pm 0.04$ & $1.15 \pm 0.05$ & $0.95 \pm 0.09$ & 0.11 \\
\hline OCFA & $2.57 \pm 0.07$ & $2.62 \pm 0.07$ & $2.61 \pm 0.07$ & $2.77 \pm 0.81$ & $2.44 \pm 0.15$ & 0.24 \\
\hline \multicolumn{7}{|c|}{ 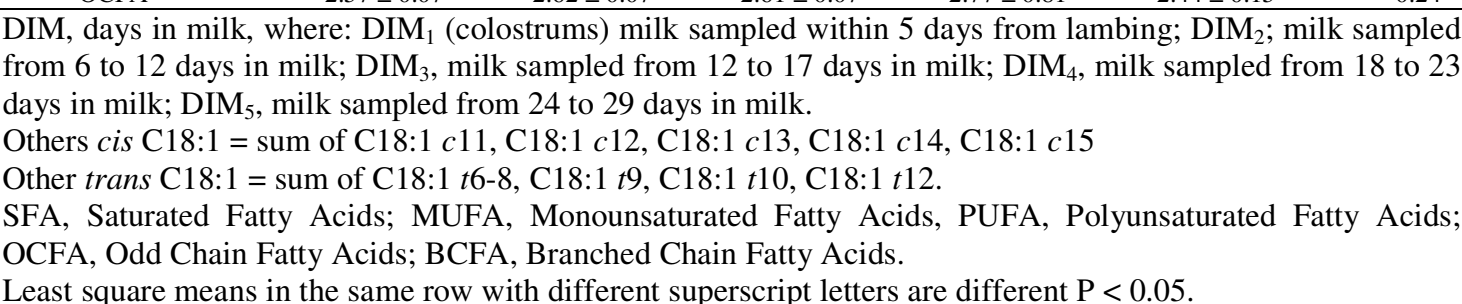 } \\
\hline
\end{tabular}

Pre-weaning lambs may be compared to non ruminant animals, because they are fed almost exclusively milk that by-passes the rumen directly to the glandular stomach by the oesophageal groove. Nevertheless in our study the lambs were kept at the pasture with their own dams, therefore, when lambs are 2-3 weeks old, they may begin to ingest also small amounts of herbage that favours the development of rumen and other pre-stomachs. Rumen activity may contribute to providing the lamb tissues with small amounts of fatty acids, including CLA and other fatty acids that originate from rumen bio-hydrogenation.

Branched chain fatty acid (BCFA) and odd chain fatty acid (OCFA) contents of meat are useful indicators of an incipient rumen activity (Berian, Purroy, TReacher, \& Bas, 2000). Unlike maternal milk (Table 6), the muscle content of these fatty acids increased with 
slaughter weight in all muscles (Table 7, Table 8 and Table 9). This may be due both to a tissue accumulation from longer time on milk of oldest lambs, and to an incipient rumen activity in the heaviest lambs. Nevertheless the OCFA and BCFA muscle content was lower (ten and five fold, respectively) than that reported by Velasco et al. (2001) in lambs slaughtered at $14 \mathrm{~kg}$ supplied with commercial concentrate, and by Aurousseau, Bauchart, Calichon, Micol, and Priolo (2004) in lambs slaughtered at $35 \mathrm{~kg}$.

Also the muscle content of VA was higher in the heavier animals even if this increase reached statistic significance only in the Sm. Nevertheless, in our study the VA content of muscle fat was lower than that reported in the literature by Priolo, Lanza, Galofaro, Fasone, and Bella (2003) and Aurousseau et al. (2004) (2.3 and $4.9 \mathrm{~g} / 100 \mathrm{~g}$ of lipids, respectively).

Table 7, Table 8 and Table 9 show the fatty acid composition (others than CLA isomers) from LD, TB and SM muscles by weight of total lipids, while Table 10, Table 11 and Table 12 show total intramuscular fat content and fatty acid composition by absolute concentration (mg/100 g muscle). The intramuscular fat content of TB was significantly higher than that of SM (2.21 and $1.81 \mathrm{~g} / 100 \mathrm{~g}$ of muscle, respectively), while LD showed an intermediate value $(2.05 \mathrm{~g} / 100 \mathrm{~g}$ of muscle). The intramuscular fat content was not affected by slaughter age (Table 10, Table 11 and Table 12), and this fact may explain why the muscle fatty acid composition remained almost stable across the slaughter ages. In all samples the ratio between polyunsaturated and saturated fatty acids ranged from 0.26 in TB from lambs slaughtered at $17 \mathrm{~kg}$ (Table 11) to 0.37 in $\mathrm{Sm}$ from lambs slaughtered at $11 \mathrm{~kg}$ (Table 12). These values are close to the nutritional advice which indicates as 0.4 the minimum value of the ratio (Wood et al., 2008). If stearic acid is not included in the saturated fatty acid sum, the P/S ratio reached higher values and it varied from 0.37 in TB from lambs slaughtered at $17 \mathrm{~kg}$ (Table 12) to $0.56 \mathrm{in} \mathrm{Sm}$ from lambs $11 \mathrm{~kg}$ weigh (Table 12). These values of $\mathrm{P} / \mathrm{S}$ ratio are similar to those reported for meat from light lambs fed mainly maternal milk (Diaz et al., 2005, Napolitano et al., 2002, Oriani et al., 2005 and Velasco et al., 2001) and lower than those reported for meat from lambs fed only maternal milk (Lanza et al., 2006a and Lanza et al., 2006b). Among SFA, C16:0 and C18:0 were the main fatty acids and their content in muscle fat tended to increase with slaughter age. The highest content of C16:0 and C18:0 was reached in TB from lambs slaughtered at $17 \mathrm{~kg}$ (434.48 and $224.24 \mathrm{mg} / 100 \mathrm{~g}$ of muscle, respectively). This could be due to the higher level of intramuscular fat in TB. 
In human diet, values of $n 6 / n 3$ ratio lower than 4 are indicated as the most favourable in order to prevent some cardiovascular diseases (Scollan et al., 2006). In our study this ratio varied from 1.30 in $\mathrm{TB}$ from animals slaughtered at $17 \mathrm{~kg}$ (Table 11) to $1.03 \mathrm{in} \mathrm{LD}$ and $\mathrm{Sm}$ from lambs slaughtered at $14 \mathrm{~kg}$ (Table 10 and Table 12).

Table 7. Fatty acid composition of meat from Longissimus dorsi muscle in lambs slaughtered at 11, 14 and $17 \mathrm{~kg}$ of live weight ( $\mathrm{g} / 100 \mathrm{~g}$ of total lipids)

\begin{tabular}{|c|c|c|c|c|c|}
\hline \multirow[b]{2}{*}{ Fatty acids } & \multicolumn{3}{|c|}{ Weight of slaughtering $(\mathrm{kg})$} & \multirow[b]{2}{*}{ SE } & \multirow[b]{2}{*}{$\mathrm{P}$} \\
\hline & $\begin{array}{c}11 \\
\mathrm{n}=6\end{array}$ & $\begin{array}{c}14 \\
\mathrm{n}=6\end{array}$ & $\begin{array}{c}17 \\
\mathrm{n}=6\end{array}$ & & \\
\hline C10:0 & 0.13 & 0.16 & 0.14 & 0.02 & 0.50 \\
\hline $\mathrm{C} 12: 0$ & 0.30 & 0.44 & 0.37 & 0.04 & 0.06 \\
\hline C13:0 & 0.01 & 0.02 & 0.01 & 0.01 & 0.13 \\
\hline C14-iso & 0.02 & 0.02 & 0.03 & 0.01 & 0.26 \\
\hline $\mathrm{C} 14: 0$ & $2.96^{\mathrm{a}}$ & $4.25^{\mathrm{b}}$ & $3.87^{\mathrm{b}}$ & 0.29 & $<0.02$ \\
\hline $\mathrm{C} 14: 1$ & $0.10^{\mathrm{A}}$ & $0.20^{\mathrm{B}}$ & $0.19^{\mathrm{B}}$ & 0.01 & $<0.01$ \\
\hline $\mathrm{C} 15$-anteiso & 0.10 & 0.15 & 0.14 & 0.02 & 0.25 \\
\hline C15:0 & $0.29^{\mathrm{Aa}}$ & $0.39^{\mathrm{b}}$ & $0.41^{\mathrm{Bb}}$ & 0.03 & 0.03 \\
\hline C16-iso & 0.09 & 0.09 & 0.13 & 0.01 & 0.14 \\
\hline $\mathrm{C} 16: 0$ & 13.51 & 14.88 & 14.78 & 0.61 & 0.24 \\
\hline $\mathrm{C} 16: 1 \mathrm{n} 7$ & $1.09^{\mathrm{a}}$ & $1.67^{\mathrm{b}}$ & $1.55^{\mathrm{b}}$ & 0.15 & 0.04 \\
\hline C17-anteiso & $0.25^{\mathrm{Aa}}$ & $0.36^{\mathrm{b}}$ & $0.44^{\mathrm{Ba}}$ & 0.04 & $<0.01$ \\
\hline $\mathrm{C} 17: 0$ & $0.57^{\mathrm{a}}$ & $0.63^{\mathrm{ab}}$ & $0.72^{\mathrm{b}}$ & 0.04 & 0.04 \\
\hline C18:0 & 8.60 & 7.87 & 7.91 & 0.26 & 0.11 \\
\hline $\mathrm{C} 18: 1 c 9$ & 22.70 & 22.84 & 22.33 & 1.07 & 0.94 \\
\hline Others C18:1 cis & 0.97 & 1.02 & 1.06 & 0.05 & 0.53 \\
\hline C18:1 $t 11$ & 1.39 & 1.56 & 1.41 & 0.18 & 0.78 \\
\hline Other trans $\mathrm{C} 18: 1$ & 0.15 & 0.20 & 0.21 & 0.03 & 0.41 \\
\hline C18:2 n6 & 2.96 & 2.82 & 2.91 & 0.25 & 0.91 \\
\hline $\mathrm{C} 18: 3 \mathrm{n} 3$ & 1.22 & 1.42 & 1.34 & 0.10 & 0.35 \\
\hline $\mathrm{C} 18: 4 \mathrm{n} 3$ & 0.03 & 0.02 & 0.03 & 0.01 & 0.95 \\
\hline C20:0 & 0.06 & 0.05 & 0.05 & 0.01 & 0.34 \\
\hline C20:1 & 0.05 & 0.04 & 0.05 & 0.01 & 0.77 \\
\hline C20:2 & 0.03 & 0.02 & 0.02 & 0.01 & 0.50 \\
\hline C20:3 n6 & 0.12 & 0.10 & 0.10 & 0.01 & 0.78 \\
\hline C20:4 n6 & 0.98 & 0.91 & 0.92 & 0.13 & 0.91 \\
\hline $\mathrm{C} 20: 5 \mathrm{n} 3$ & 0.93 & 0.94 & 0.90 & 0.14 & 0.97 \\
\hline C22:1 n9 & 0.04 & 0.04 & 0.03 & 0.01 & 0.42 \\
\hline $\mathrm{C} 22: 5 \mathrm{n} 3$ & 1.01 & 0.84 & 0.72 & 0.11 & 0.21 \\
\hline $\mathrm{C} 22: 6 \mathrm{n} 3$ & 0.52 & 0.57 & 0.43 & 0.09 & 0.58 \\
\hline SFA & 26.49 & 28.75 & 28.22 & 0.87 & 0.19 \\
\hline MUFA & 26.56 & 27.66 & 26.89 & 1.12 & 0.78 \\
\hline PUFA n6 & 4.11 & 3.90 & 3.98 & 0.38 & 0.92 \\
\hline PUFA n3 & 3.71 & 3.82 & 3.36 & 0.39 & 0.69 \\
\hline BCFA & $0.47^{\mathrm{Aa}}$ & $0.63^{\mathrm{b}}$ & $0.76^{\mathrm{Ba}}$ & 0.06 & $<0.01$ \\
\hline OCFA & $0.90^{\mathrm{a}}$ & $1.12^{\mathrm{b}}$ & $1.11^{\mathrm{b}}$ & 0.06 & 0.02 \\
\hline $\begin{array}{l}\text { C11:0, C13:0, C20:3 n } \\
\text { lipids } \\
\text { SFA, Saturated Fatty } \\
\text { BCFA, Branched Chair } \\
\text { Others trans C18:1: sur } \\
\text { Others cis C18:1: sum } \\
\text { Least square means in } \\
\text { capital p < } 0.01 \text {. }\end{array}$ & $\begin{array}{l}\text { and } \mathrm{C} 2 \\
\text { IUFA, I } \\
\text { cids; OC } \\
1 t 12 \text { ar } \\
c 11, \mathrm{C} 1 \\
\text { row w }\end{array}$ & $\begin{array}{l}\text { detecte } \\
\text { saturat } \\
\text { dd Chai } \\
1 \text { t9. } \\
2, \mathrm{C} 18 \text { : } \\
\text { erent }\end{array}$ & $\begin{array}{l}\text { are not } r \\
\text { y Acids } \\
\text { acids. } \\
\text { ad C18: } \\
\text { ipt letter }\end{array}$ & rent: sn & $\begin{array}{l}0 \mathrm{~g} \text { of total } \\
\mathrm{p}<0.05 \text {, }\end{array}$ \\
\hline
\end{tabular}


These values agreed with those reported by (Wood et al., 2008), (Diaz et al., 2005), (Oriani et al., 2005), (Napolitano et al., 2002) and (Velasco et al., 2001) in ovine meat from light lambs fed mainly maternal milk, but (Lanza et al., 2006a) and (Lanza et al., 2006b) reported a higher $n 6 / n 3$ ratio (2.61), in muscle fat from lambs fed only maternal milk.

Table 8. Fatty acid composition of meat from Triceps brachii muscle in lambs slaughtered at 11, 14 and 17 $\mathrm{kg}$ of live weight $(\mathrm{g} / 100 \mathrm{~g}$ of total lipids)

\begin{tabular}{|c|c|c|c|c|c|}
\hline \multirow[b]{2}{*}{ Fatty acids } & \multicolumn{3}{|c|}{ Weight of slaughtering $(\mathrm{kg})$} & \multirow[b]{2}{*}{ SE } & \multirow[b]{2}{*}{$\mathrm{P}$} \\
\hline & $\begin{array}{c}11 \\
\mathrm{n}=6\end{array}$ & $\begin{array}{c}14 \\
\mathrm{n}=6\end{array}$ & $\begin{array}{c}17 \\
n=6\end{array}$ & & \\
\hline C10:0 & 0.08 & 0.11 & 0.10 & 0.02 & 0.66 \\
\hline C12:0 & 0.25 & 0.32 & 0.34 & 0.04 & 0.33 \\
\hline C14-iso & 0.02 & 0.02 & 0.03 & 0.01 & 0.79 \\
\hline C14:0 & 2.44 & 2.98 & 3.46 & 0.38 & 0.20 \\
\hline $\mathrm{C} 14: 1$ & $0.11^{\mathrm{a}}$ & $0.18^{\mathrm{b}}$ & $0.20^{\mathrm{b}}$ & 0.02 & 0.03 \\
\hline C15-anteiso & $0.10^{\mathrm{Aa}}$ & $0.18^{\mathrm{Bb}}$ & $0.15^{\mathrm{bA}}$ & 0.02 & $<0.01$ \\
\hline C15:0 & $0.28^{\mathrm{a}}$ & $0.40^{\mathrm{b}}$ & $0.42^{\mathrm{b}}$ & 0.03 & 0.02 \\
\hline C16-iso & 0.09 & 0.10 & 0.12 & 0.01 & 0.30 \\
\hline C16:0 & 11.08 & 10.80 & 12.75 & 0.85 & 0.25 \\
\hline $\mathrm{C} 16: 1 \mathrm{n} 7$ & 0.55 & 0.82 & 0.84 & 0.19 & 0.50 \\
\hline C17-anteiso & 0.28 & 0.35 & 0.40 & 0.03 & 0.06 \\
\hline $\mathrm{C} 17: 0$ & 0.51 & 0.68 & 0.70 & 0.08 & 0.21 \\
\hline C18:0 & 6.53 & 6.15 & 6.62 & 0.55 & 0.81 \\
\hline C18:1 cis 9 & 20.13 & 18.69 & 20.14 & 1.60 & 0.77 \\
\hline Others C18:1 cis & 0.79 & 0.68 & 0.77 & 0.07 & 0.46 \\
\hline C18:1 trans 11 & 1.34 & 1.29 & 1.70 & 0.17 & 0.20 \\
\hline Other trans $\mathrm{C} 18: 1$ & 0.25 & 0.22 & 0.31 & 0.03 & 0.10 \\
\hline $\mathrm{C} 18: 2 \mathrm{n} 6$ & 2.72 & 2.44 & 2.30 & 0.25 & 0.49 \\
\hline $\mathrm{C} 18: 3 \mathrm{n} 3$ & 1.07 & 1.00 & 1.00 & 0.12 & 0.88 \\
\hline $\mathrm{C} 18: 4 \mathrm{n} 3$ & 0.02 & 0.02 & 0.01 & 0.01 & 0.19 \\
\hline C20:0 & 0.06 & 0.04 & 0.04 & 0.01 & 0.15 \\
\hline C20:1 & 0.04 & 0.03 & 0.02 & 0.01 & 0.12 \\
\hline C20:2 & 0.02 & 0.02 & 0.02 & 0.01 & 0.48 \\
\hline C20:3 n6 & 0.09 & 0.08 & 0.07 & 0.01 & 0.38 \\
\hline C20:4 n6 & 0.99 & 0.86 & 0.67 & 0.12 & 0.19 \\
\hline C20:5 n3 & 0.72 & 0.77 & 0.53 & 0.08 & 0.12 \\
\hline $\mathrm{C} 22: 1 \mathrm{n} 9$ & 0.04 & 0.03 & 0.02 & 0.01 & 0.47 \\
\hline $\mathrm{C} 22: 5 \mathrm{n} 3$ & 0.80 & 0.69 & 0.52 & 0.08 & 0.08 \\
\hline $\mathrm{C} 22: 6 \mathrm{n} 3$ & 0.42 & 0.45 & 0.27 & 0.06 & 0.14 \\
\hline SFA & 21.14 & 21.18 & 24.25 & 1.60 & 0.31 \\
\hline MUFA & 23.24 & 21.89 & 23.98 & 1.88 & 0.73 \\
\hline PUFA n6 & 3.82 & 3.55 & 3.08 & 0.33 & 0.30 \\
\hline PUFA n3 & 3.04 & 2.94 & 2.34 & 0.27 & 0.17 \\
\hline BCFA & $0.50^{\mathrm{aA}}$ & $0.65^{\mathrm{bA}}$ & $0.70^{\mathrm{B}}$ & 0.05 & 0.02 \\
\hline OCFA & 1.12 & 1.61 & 1.64 & 0.13 & 0.06 \\
\hline $\begin{array}{l}\text { C11:0, C13:0, C20:3 n } \\
\text { lipids } \\
\text { SFA, Saturated Fatty } \\
\text { BCFA, Branched Chain } \\
\text { Others trans C18:1: sun } \\
\text { Others cis C18:1: sum } \\
\text { Least square means in } \\
\text { capital p < } 0.01 \text {. }\end{array}$ & $\begin{array}{l}\text { and } \mathrm{C} 2 \\
\text { IUFA, I } \\
\text { cids; OC } \\
1 t 12 \text { ar } \\
c 11, \mathrm{C} 1 \\
\text { row w }\end{array}$ & $\begin{array}{l}\text { detecte } \\
\text { isaturate } \\
\text { dd Chair } \\
1 t 9 . \\
2, \text { C } 18: 1 \\
\text { erent su }\end{array}$ & $\begin{array}{l}\text { re not re } \\
\text { Acids; } \\
\text { acids. } \\
\text { d C18:1 } \\
\text { pt letter }\end{array}$ & $\mathrm{t}: \mathrm{sm}$ & $\begin{array}{l}\text { g of total } \\
\text { ty Acids; } \\
\text { p }<0.05 \text {, }\end{array}$ \\
\hline
\end{tabular}


Table 9. Fatty acid composition of meat from Semimembranosus muscle in lambs slaughtered at 11, 14 and $17 \mathrm{~kg}$ of live weight $(\mathrm{g} / 100 \mathrm{~g}$ of total lipids)

\begin{tabular}{|c|c|c|c|c|c|}
\hline \multirow{3}{*}{ Fatty acids } & \multicolumn{3}{|c|}{ Weight of slaughtering $(\mathrm{kg})$} & \multirow{3}{*}{ SE } & \multirow{3}{*}{$\mathrm{P}$} \\
\hline & \multirow{2}{*}{$\begin{array}{c}11 \\
n=6\end{array}$} & \multirow{2}{*}{$\begin{array}{c}14 \\
\mathrm{n}=6\end{array}$} & \multirow{2}{*}{$\begin{array}{c}17 \\
\mathrm{n}=6\end{array}$} & & \\
\hline & & & & & \\
\hline C10:0 & 0.08 & 0.11 & 0.07 & 0.01 & 0.31 \\
\hline C12:0 & 0.23 & 0.36 & 0.27 & 0.04 & 0.10 \\
\hline C14:0 & 2.35 & 3.26 & 3.06 & 0.33 & 0.16 \\
\hline $\mathrm{C} 14: 1$ & $0.08^{\mathrm{A}}$ & $0.14^{\mathrm{B}}$ & $0.13^{\mathrm{B}}$ & 0.01 & 0.02 \\
\hline C15-anteiso & $0.09^{\mathrm{a}}$ & $0.14^{\mathrm{b}}$ & $0.13^{\mathrm{b}}$ & 0.01 & 0.04 \\
\hline $\mathrm{C} 15: 0$ & $0.25^{\mathrm{a}}$ & $0.38^{\mathrm{b}}$ & $0.37^{\mathrm{b}}$ & 0.03 & 0.02 \\
\hline C16-iso & 0.08 & 0.11 & 0.10 & 0.08 & 0.12 \\
\hline $\mathrm{C} 16: 0$ & 10.81 & 11.62 & 11.40 & 0.84 & 0.78 \\
\hline C16:1 n7 & 0.72 & 0.65 & 0.67 & 0.14 & 0.94 \\
\hline C17-anteiso & $0.23^{\mathrm{aA}}$ & $0.30^{\mathrm{b}}$ & $0.38^{\mathrm{Ba}}$ & 0.02 & $<0.01$ \\
\hline C17:0 & 0.55 & 0.59 & 0.68 & 0.04 & 0.12 \\
\hline C18:0 & 7.22 & 6.58 & 6.34 & 0.37 & 0.25 \\
\hline $\mathrm{C} 18: 1 c 9$ & 19.33 & 18.19 & 18.03 & 1.12 & 0.68 \\
\hline Others C18:1 cis & 0.90 & 0.86 & 0.75 & 0.82 & 0.40 \\
\hline $\mathrm{C} 18: 1 t 11$ & 1.25 & 1.42 & 1.45 & 0.12 & 0.46 \\
\hline Other trans $\mathrm{C} 18: 1$ & 0.23 & 0.23 & 0.26 & 0.03 & 0.82 \\
\hline C18:2 n6 & 2.78 & 2.48 & 2.56 & 0.23 & 0.64 \\
\hline $\mathrm{C} 18: 3 \mathrm{n} 3$ & 1.15 & 1.19 & 1.06 & 0.07 & 0.41 \\
\hline $\mathrm{C} 18: 4 \mathrm{n} 3$ & 0.03 & 0.02 & 0.03 & 0.01 & 0.95 \\
\hline C20:0 & 0.07 & 0.06 & 0.05 & 0.01 & 0.34 \\
\hline C20:1 & 0.05 & 0.04 & 0.05 & 0.01 & 0.77 \\
\hline C20:2 & 0.03 & 0.02 & 0.02 & 0.01 & 0.50 \\
\hline $\mathrm{C} 20: 3 \mathrm{n} 6$ & 0.12 & 0.10 & 0.10 & 0.01 & 0.77 \\
\hline C20:4 n6 & 1.08 & 0.85 & 0.86 & 0.12 & 0.84 \\
\hline C20:5 n3 & 0.94 & 0.86 & 0.77 & 0.11 & 0.59 \\
\hline $\mathrm{C} 22: 1 \mathrm{n} 9$ & 0.04 & 0.04 & 0.03 & 0.01 & 0.42 \\
\hline $\mathrm{C} 22: 5 \mathrm{n} 3$ & $1.02^{\mathrm{a}}$ & $0.78^{\mathrm{ab}}$ & $0.71^{\mathrm{b}}$ & 0.07 & 0.02 \\
\hline $\mathrm{C} 22: 6 \mathrm{n} 3$ & 0.66 & 0.52 & 0.39 & 0.10 & 0.58 \\
\hline SFA & 21.51 & 22.81 & 22.02 & 1.50 & 0.83 \\
\hline MUFA & 22.60 & 21.57 & 21.34 & 1.26 & 0.76 \\
\hline PUFA n6 & 3.96 & 3.43 & 3.52 & 0.34 & 0.53 \\
\hline PUFA n3 & 3.82 & 3.36 & 2.95 & 0.30 & 0.16 \\
\hline BCFA & $0.41^{\mathrm{aA}}$ & $0.57^{\mathrm{b}}$ & $0.63^{\mathrm{B}}$ & 0.04 & $<0.01$ \\
\hline OCFA & $1.18^{\mathrm{Aa}}$ & $1.43^{\mathrm{b}}$ & $1.57^{\mathrm{B}}$ & 0.09 & 0.02 \\
\hline $\begin{array}{l}\text { C11:0, C13:0, C14-iso, } \\
\text { of total lipids }\end{array}$ & 3, C24: & $24: 0$ are & ed but & rted b & $\mathrm{mg} / 100 \mathrm{~g}$ \\
\hline $\begin{array}{l}\text { SFA, Saturated Fatty } \\
\text { BCFA, Branched Chain }\end{array}$ & $\begin{array}{l}\text { IUFA, I } \\
\text { cids; OC }\end{array}$ & $\begin{array}{l}\text { saturate } \\
\text { dd Chair }\end{array}$ & $\begin{array}{l}\text { y Acids } \\
\text { acids. }\end{array}$ & blyuns & ty Acids; \\
\hline Others trans C18:1: sun & $: 1 t 12$ ar & $1 t 9$ & & & \\
\hline Others cis C18:1: sum & $c 11, \mathrm{C} 1$ & , C18:1 & d C18: 1 & & \\
\hline $\begin{array}{l}\text { Least square means in } \\
\text { capital } p<0.01 \text {. }\end{array}$ & row $\mathrm{w}$ & erent su & pt letter & nt: s & $\mathrm{p}<0.05$ \\
\hline
\end{tabular}

Linoleic acid was the main polyunsaturated fatty acid, ranging from $3.08 \mathrm{~g} / 100 \mathrm{~g}$ of muscle fat in TB from $17 \mathrm{~kg}$ weight lambs (Table 8 ) to $4.11 \mathrm{~g} / 100 \mathrm{~g}$ of muscle fat in LD from lambs slaughtered at $11 \mathrm{~kg}$ of body weight (Table 7). Total $n-6$ polyunsaturated fatty acids ranged from $72.03 \mathrm{mg} / 100 \mathrm{~g}$ of muscle in Sm (Table 12) to $97.64 \mathrm{mg} / 100 \mathrm{~g}$ of muscle in TB (Table 11). Total $n-3$ polyunsaturated fatty acids ranged from $2.34 \mathrm{~g} / 100 \mathrm{~g}$ of muscle 
fat in TB (Table 8) to $3.82 \mathrm{~g} / 100 \mathrm{~g}$ of muscle fat in Sm (Table 9). By weight of $100 \mathrm{~g}$ of muscle, total $n-3$ polyunsaturated fatty acids ranged from $72.03 \mathrm{mg}$ in Sm (Table 12), to 89.01 in LD (Table 10).

Table 10. Lipid content and fatty acid composition of meat from Longissimus dorsi muscle in lambs slaughtered at 11,14 and $17 \mathrm{~kg}$ of live weight (mg/100g of muscle)

\begin{tabular}{|c|c|c|c|c|c|}
\hline \multirow[b]{2}{*}{ Fatty acids } & \multicolumn{3}{|c|}{ Weight of slaughtering $(\mathrm{kg})$} & \multirow[b]{2}{*}{ SE } & \multirow[b]{2}{*}{$\mathrm{P}$} \\
\hline & $\begin{array}{c}11 \\
n=6\end{array}$ & $\begin{array}{c}14 \\
n=6\end{array}$ & $\begin{array}{c}17 \\
n=6\end{array}$ & & \\
\hline Total Lipids & 1956.66 & 1995.00 & 2196.67 & 127.18 & 0.38 \\
\hline C10:0 & 2.71 & 3.28 & 3.38 & 0.54 & 0.65 \\
\hline C12:0 & 5.92 & 9.00 & 8.89 & 1.26 & 0.18 \\
\hline $\mathrm{C} 14: 0$ & 58.84 & 86.02 & 92.83 & 11.34 & 0.11 \\
\hline $\mathrm{C} 14: 1$ & $2.01^{\mathrm{a}}$ & $4.01^{\mathrm{ab}}$ & $4.18^{\mathrm{b}}$ & 0.58 & 0.03 \\
\hline C15-anteiso & 2.04 & 3.04 & 3.19 & 0.51 & 0.26 \\
\hline C15:0 & 5.82 & 7.98 & 9.14 & 0.93 & 0.07 \\
\hline C16-iso & 1.86 & 1.83 & 2.80 & 0.31 & 0.07 \\
\hline C16:0 & 265.97 & 298.97 & 349.23 & 31.41 & 0.20 \\
\hline $\mathrm{C} 16: 1 \mathrm{n} 7$ & 21.98 & 33.32 & 37.13 & 4.74 & 0.09 \\
\hline C17-anteiso & $5.01^{\mathrm{b}}$ & $7.33^{\mathrm{ab}}$ & $9.87^{\mathrm{a}}$ & 1.06 & 0.02 \\
\hline $\mathrm{C} 17: 0$ & 11.16 & 12.73 & 15.91 & 1.29 & 0.06 \\
\hline C18:0 & 168.49 & 156.61 & 185.92 & 13.77 & 0.34 \\
\hline $\mathrm{C} 18: 1 c 9$ & 443.50 & 457.34 & 526.95 & 46.30 & 0.41 \\
\hline Others C18:1 cis & 15.43 & 16.33 & 18.57 & 1.30 & 0.25 \\
\hline $\mathrm{C} 18: 1 t 11$ & 27.61 & 31.89 & 38.87 & 4.04 & 0.17 \\
\hline Other trans $\mathrm{C} 18: 1$ & 4.18 & 5.68 & 7.18 & 1.20 & 0.24 \\
\hline C18:2 n6 & 57.83 & 54.82 & 63.02 & 4.29 & 0.41 \\
\hline $\mathrm{C} 18: 3$ n3 & 23.83 & 28.08 & 29.16 & 2.28 & 0.25 \\
\hline C20:0 & 1.27 & 1.11 & 1.26 & 0.11 & 0.52 \\
\hline C20:1 & 0.96 & 0.87 & 1.09 & 0.14 & 0.56 \\
\hline C20:3 n6 & 2.29 & 1.96 & 2.31 & 0.26 & 0.58 \\
\hline C20:4 n6 & 19.27 & 17.43 & 20.09 & 2.32 & 0.71 \\
\hline C20:5 n3 & 18.40 & 18.14 & 19.66 & 2.75 & 0.92 \\
\hline C22:1 n9 & 0.81 & 0.82 & 0.68 & 0.13 & 0.72 \\
\hline $\mathrm{C} 22: 5 \mathrm{n} 3$ & 19.70 & 16.44 & 15.71 & 2.03 & 0.36 \\
\hline $\mathrm{C} 22: 6 \mathrm{n} 3$ & 10.25 & 11.19 & 9.39 & 1.95 & 0.81 \\
\hline Total CLA & 28.41 & 30.51 & 37.37 & 4.04 & 0.29 \\
\hline SFA & 530.55 & 589.22 & 683.94 & 59.37 & 0.22 \\
\hline MUFA & 521.75 & 557.97 & 645.15 & 56.84 & 0.32 \\
\hline PUFA n6 & 80.32 & 75.54 & 90.18 & 6.16 & 0.26 \\
\hline PUFA n3 & 72.89 & 74.48 & 74.68 & 7.42 & 0.98 \\
\hline $\mathrm{P} / \mathrm{S}$ & 0.31 & 0.29 & 0.28 & 0.02 & 0.70 \\
\hline $\mathrm{P} / \mathrm{S} 2$ & 0.46 & 0.40 & 0.39 & 0.04 & 0.40 \\
\hline n6/n3 & 1.12 & 1.03 & 1.26 & 0.09 & 0.21 \\
\hline $\begin{array}{l}\text { C11:0, C13:0, C14-is } \\
\text { because < } 0.5 \mathrm{mg} / 100 \\
\text { SFA, Saturated Fatty } \\
\text { Others trans } \mathrm{C} 18: 1: \mathrm{s} \\
\text { Others cis C18:1: sun } \\
\text { P/S, PUFA/SFA } \\
\text { P/S2, PUFA/(SFA-C1 } \\
\text { Least square means in }\end{array}$ & $\begin{array}{l}3: 4 \mathrm{n} 3, \mathrm{C} \\
\text { ascle } \\
\text { MUFA, N } \\
\text { C18:1 t6- } \\
8: 1 c 11,\end{array}$ & $\begin{array}{l}20: 3 \mathrm{n} 3, \\
\text { saturated } \\
1 t 9 \text { and C } \\
12, \mathrm{C} 18: 1\end{array}$ & $\begin{array}{l}\text { and C24: } \\
\text { cids; PUF } \\
2 . \\
\text { C C18:1 } 1 \text {. }\end{array}$ & cted but & $\begin{array}{l}\text { eporte } \\
\text { ds. }\end{array}$ \\
\hline
\end{tabular}


Table 11. Lipid content and fatty acid composition of meat from Triceps brachii muscle in lambs slaughtered at 11,14 and $17 \mathrm{~kg}$ of live weight ( $\mathrm{mg} / 100 \mathrm{~g}$ of muscle)

\begin{tabular}{|c|c|c|c|c|c|}
\hline \multirow[b]{2}{*}{ Fatty acids } & \multicolumn{3}{|c|}{ Weight of slaughtering $(\mathrm{kg})$} & \multirow[b]{2}{*}{ SE } & \multirow[b]{2}{*}{$\mathrm{P}$} \\
\hline & $\begin{array}{c}11 \\
\mathrm{n}=6\end{array}$ & $\begin{array}{c}14 \\
\mathrm{n}=6\end{array}$ & $\begin{array}{c}17 \\
\mathrm{n}=6\end{array}$ & & \\
\hline Total Lipids & 1978.33 & 2021.66 & 2645.00 & 325.64 & 0.30 \\
\hline $\mathrm{C} 10: 0$ & 2.10 & 3.09 & 3.84 & 0.92 & 0.42 \\
\hline $\mathrm{C} 12: 0$ & 5.97 & 9.34 & 11.75 & 2.19 & 0.21 \\
\hline $\mathrm{C} 14: 0$ & 59.33 & 87.15 & 121.81 & 22.60 & 0.18 \\
\hline $\mathrm{C} 14: 1$ & 2.18 & 3.60 & 5.54 & 0.96 & 0.07 \\
\hline C15-anteiso & 2.00 & 3.77 & 4.15 & 0.79 & 0.16 \\
\hline $\mathrm{C} 15: 0$ & 5.71 & 8.19 & 11.70 & 2.12 & 0.17 \\
\hline C16-iso & 1.86 & 1.90 & 3.30 & 0.56 & 0.15 \\
\hline C16:0 & 268.63 & 316.68 & 434.48 & 63.63 & 0.20 \\
\hline C16:1 n7 & 13.60 & 24.82 & 31.57 & 9.33 & 0.41 \\
\hline C17-anteiso & 5.64 & 7.09 & 11.69 & 2.43 & 0.22 \\
\hline $\mathrm{C} 17: 0$ & 10.27 & 13.69 & 20.43 & 4.24 & 0.26 \\
\hline C18:0 & 155.42 & 179.61 & 224.24 & 32.21 & 0.33 \\
\hline $\mathrm{C} 18: 1$ cis 9 & 489.92 & 546.06 & 690.33 & 108.65 & 0.42 \\
\hline Others C18:1 cis & 16.82 & 17.59 & 17.24 & 1.63 & 0.94 \\
\hline C18:1 trans 11 & 32.37 & 38.08 & 59.66 & 10.85 & 0.20 \\
\hline Other trans $\mathrm{C} 18: 1$ & 6.66 & 6.99 & 10.09 & 1.03 & 0.06 \\
\hline $\mathrm{C} 18: 2 \mathrm{n} 6$ & 64.47 & 70.44 & 70.45 & 5.59 & 0.69 \\
\hline C18:3 n3 & 25.58 & 33.16 & 31.42 & 2.11 & 0.06 \\
\hline $\mathrm{C} 20: 0$ & 1.43 & 1.11 & 1.51 & 0.27 & 0.55 \\
\hline C20:1 & 0.88 & 0.80 & 0.53 & 0.17 & 0.34 \\
\hline C20:3 n6 & 2.20 & 2.40 & 1.96 & 0.31 & 0.61 \\
\hline $\mathrm{C} 20: 4 \mathrm{n} 6$ & 23.35 & 24.15 & 20.14 & 2.66 & 0.54 \\
\hline $\mathrm{C} 20: 5 \mathrm{n} 3$ & 16.83 & 21.77 & 16.15 & 1.61 & 0.06 \\
\hline $\mathrm{C} 22: 1 \mathrm{n} 9$ & 0.89 & 0.89 & 0.65 & 0.21 & 0.65 \\
\hline $\mathrm{C} 22: 5 \mathrm{n} 3$ & 18.95 & 20.49 & 15.72 & 2.25 & 0.34 \\
\hline $\mathrm{C} 22: 6 \mathrm{n} 3$ & 10.12 & 12.77 & 8.37 & 1.44 & 0.13 \\
\hline Total CLA & 27.76 & 35.92 & 54.07 & 9.36 & 0.16 \\
\hline SFA & 519.75 & 633.28 & 850.77 & 128.17 & 0.21 \\
\hline MUFA & 573.40 & 651.61 & 840.21 & 135.11 & 0.38 \\
\hline PUFA n6 & 90.29 & 97.64 & 93.62 & 7.65 & 0.80 \\
\hline PUFA n3 & 72.03 & 89.01 & 72.29 & 5.22 & 0.06 \\
\hline $\mathrm{P} / \mathrm{S}$ & 0.34 & 0.32 & 0.26 & 0.02 & 0.12 \\
\hline $\mathrm{P} / \mathrm{S} 2$ & 0.49 & 0.46 & 0.37 & 0.04 & 0.12 \\
\hline $\mathrm{n} 6 / \mathrm{n} 3$ & 1.29 & 1.28 & 1.30 & 0.13 & 0.99 \\
\hline $\begin{array}{l}\text { C11:0, C13:0, C14-is } \\
\text { because < } 0.5 \mathrm{mg} / 100 \\
\text { SFA, Saturated Fatty } \\
\text { Others trans C18:1: sl } \\
\text { Others cis C18:1: sun } \\
\text { P/S, PUFA/SFA } \\
\text { P/S2, PUFA/(SFA-C1 }\end{array}$ & $\begin{array}{l}3: 4 \mathrm{n} 3, \mathrm{C} \\
\text { uscle } \\
\text { MUFA, N } \\
\text { C18:1 t6- } \\
8: 1 \mathrm{c} 11 \text {, }\end{array}$ & $\begin{array}{l}20: 3 \mathrm{n} 3, \\
\text { saturated } \\
1 \text { t } 9 \text { and C } \\
12, \mathrm{C} 18: 1\end{array}$ & $\begin{array}{l}\text { and C24: } \\
\text { cids; PUF } \\
2 . \\
\text { d C18:1 }\end{array}$ & $\begin{array}{l}\text { cted but } \\
\text { saturated }\end{array}$ & eporte \\
\hline
\end{tabular}


Table 12. lipids content and fatty acid composition of meat from Semimembranosus muscle in lambs slaughtered at 11,14 and $17 \mathrm{~kg}$ of live weight (mg/100g of muscle)

\begin{tabular}{|c|c|c|c|c|c|}
\hline \multirow[b]{2}{*}{ Fatty acids } & \multicolumn{3}{|c|}{ Weight of slaughtering $(\mathrm{kg})$} & \multirow[b]{2}{*}{ SE } & \multirow[b]{2}{*}{$\mathrm{P}$} \\
\hline & $\begin{array}{c}11 \\
n=6\end{array}$ & $\begin{array}{c}14 \\
n=6\end{array}$ & $\begin{array}{c}17 \\
\mathrm{n}=6\end{array}$ & & \\
\hline Total lipids & 1796.66 & 1843.33 & 1778.33 & 101.75 & 0.90 \\
\hline C10:0 & 1.73 & 2.37 & 1.89 & 0.29 & 0.30 \\
\hline $\mathrm{C} 12: 0$ & 4.82 & 8.11 & 6.55 & 0.88 & 0.06 \\
\hline $\mathrm{C} 14: 0$ & 0.24 & 0.35 & 0.26 & 0.12 & 0.79 \\
\hline $\mathrm{C} 14: 1$ & $1.77^{\mathrm{b}}$ & $3.24^{\mathrm{a}}$ & $3.17^{\mathrm{a}}$ & 0.33 & 0.02 \\
\hline C15-anteiso & 1.64 & 2.55 & 2.36 & 0.31 & 0.12 \\
\hline $\mathrm{C} 15: 0$ & 4.61 & 6.99 & 6.73 & 0.78 & 0.09 \\
\hline C16-iso & 1.53 & 2.03 & 1.83 & 0.22 & 0.29 \\
\hline $\mathrm{C} 16: 0$ & 230.35 & 266.79 & 274.25 & 26.58 & 0.47 \\
\hline C16:1 n7 & 14.71 & 14.86 & 15.78 & 2.88 & 0.96 \\
\hline C17-anteiso & 4.13 & 5.67 & 6.89 & 0.74 & 0.06 \\
\hline $\mathrm{C} 17: 0$ & 9.95 & 11.04 & 12.20 & 1.25 & 0.47 \\
\hline C18:0 & 151.81 & 152.66 & 153.12 & 14.09 & 0.99 \\
\hline $\mathrm{C} 18: 1 c 9$ & 410.25 & 421.26 & 436.66 & 44.45 & 0.91 \\
\hline Others C18:1 cis & 17.31 & 17.44 & 15.48 & 2.20 & 0.78 \\
\hline $\mathrm{C} 18: 1 t 11$ & 26.08 & 33.33 & 35.32 & 4.14 & 0.28 \\
\hline Other trans $\mathrm{C} 18: 1$ & 5.48 & 5.98 & 6.57 & 0.88 & 0.69 \\
\hline $\mathrm{C} 18: 2 \mathrm{n} 6$ & 58.53 & 58.24 & 59.95 & 6.38 & 0.98 \\
\hline $\mathrm{C} 18: 3 \mathrm{n} 3$ & 24.22 & 27.73 & 25.00 & 2.41 & 0.57 \\
\hline $\mathrm{C} 20: 0$ & 1.21 & 1.07 & 0.87 & 0.18 & 0.44 \\
\hline C20:1 & 0.83 & 0.63 & 0.65 & 0.21 & 0.76 \\
\hline C20:3 n6 & 2.03 & 2.04 & 2.22 & 0.28 & 0.87 \\
\hline C20:4 n6 & 22.58 & 19.68 & 19.91 & 2.71 & 0.71 \\
\hline C20:5 n3 & 19.72 & 19.78 & 17.92 & 2.66 & 0.85 \\
\hline C22:1 n9 & 1.04 & 0.88 & 0.48 & 0.17 & 0.09 \\
\hline $\mathrm{C} 22: 5 \mathrm{n} 3$ & 21.48 & 18.02 & 16.76 & 1.91 & 0.23 \\
\hline $\mathrm{C} 22: 6 \mathrm{n} 3$ & 13.90 & 12.08 & 9.27 & 2.23 & 0.36 \\
\hline Total CLA & 23.93 & 28.81 & 33.54 & 3.31 & 0.15 \\
\hline SFA & 462.71 & 534.39 & 526.19 & 50.66 & 0.56 \\
\hline MUFA & 485.87 & 508.83 & 525.08 & 50.43 & 0.86 \\
\hline PUFA n6 & 83.32 & 80.37 & 82.21 & 9.01 & 0.97 \\
\hline PUFA n3 & 80.02 & 78.05 & 69.40 & 8.19 & 0.63 \\
\hline $\mathrm{P} / \mathrm{S}$ & 0.37 & 0.32 & 0.33 & 0.03 & 0.50 \\
\hline $\mathrm{P} / \mathrm{S} 2$ & 0.56 & 0.44 & 0.48 & 0.05 & 0.28 \\
\hline $\mathrm{n} 6 / \mathrm{n} 3$ & 1.04 & 1.03 & 1.20 & 0.06 & 0.11 \\
\hline $\begin{array}{l}\text { C11:0, C13:0, C14-i } \\
\text { because < } 0.5 \mathrm{mg} / 100 \\
\text { SFA, Saturated Fatty } \\
\text { Others trans C18:1: } \\
\text { Others cis C18:1: sur } \\
\text { P/S, PUFA/SFA } \\
\text { P/S2, PUFA/(SFA-C1 } \\
\text { Least square means in }\end{array}$ & $\begin{array}{l}\text { :4 n3, C } \\
\text { ascle. } \\
\text { MUFA, } \\
\text { C18:1 } t 6- \\
8: 1 c 11,\end{array}$ & $\begin{array}{l}20: 3 \mathrm{n} 3, \\
\text { saturated } \\
1 \text { t } 9 \text { and C } \\
12, \mathrm{C} 18: 1\end{array}$ & $\begin{array}{l}\text { and } \mathrm{C} 24 \\
\text { cids; PUF } \\
2 . \\
\text { d C18:1 }\end{array}$ & $\begin{array}{l}\text { cted but } \\
\text { aturated }\end{array}$ & $\begin{array}{l}\text { eporte } \\
\text { ds. }\end{array}$ \\
\hline
\end{tabular}

In our study, the content of oleic acid and total monounsaturated fatty acids in muscle fat reached higher values than those reported by Oriani et al. (2005) and Velasco et al. (2001), but agreed to those reported by (Diaz et al., 2005) and (Napolitano et al., 2002) and Wood et al. (2008). By weight of total lipids, cis-9 C18:1 varied from 18.03 g in Sm (Table 9) to 
$22.84 \mathrm{~g}$ in LD (Table 7). By $\mathrm{mg}$ of $100 \mathrm{~g}$ of muscle, oleic acid ranged from 410.25 in $\mathrm{Sm}$ (Table 12), to $690.33 \mathrm{mg}$ in TB (Table 11). These values are lower than those reported by Diaz et al. (2005).

\section{Conclusions}

Our study showed that the body weight at slaughter significantly affected the amount of RA in intramuscular fat of Sm and TB in Massese lambs, but not in the LD. In particular, the heaviest animals showed the highest amount of RA, probably due either to a higher intake of RA, for longer time on milk or to a higher tissue activity of SCD enzyme or to an incipient rumen activity. Indeed, SCD enzyme activity (estimated by means of desaturation index of miristic to miristoleic acid) and rumen activity (estimated by means of BCFA and OCFA content in meat fat) increased with the slaughter time. The different behaviour shown by LD muscle did not seem to be related either to differences in the SCD activity, or to differences in the rumen activity, or to differences in fat deposition. Thus, further studies are needed to verify whether this different behaviour among muscles is related to their different metabolism and/or to a different tissue utilisation of fatty acids. As a matter of fact, LD is believed to be a glycolytic muscle containing more than $80 \% \alpha$-white fibres while Sm and $\mathrm{TB}$ are believed to be oxidative muscles (Alasnier, David-Briand, \& Gandemer, 2000). Many enzymes (i.e. muscular lipoProtein lipase, fatty acids binding proteins, and hormone-sensitive lipase), which play an important role in skeletal muscle metabolism, show a different expression and/or activity in oxidative muscles than in glycolytic muscles (Kokta, Dodson, Gertler, \& Hill, 2004). 


\section{References}

C. Alasnier, E. David-Briand and G. Gandemer, Lipolysis in muscles during refrigerated storage as related to the metabolic type of the fibres I the rabbit, Meat Science 54 (2000), pp. 127-134.

B. Aurousseau, D. Bauchart, E. Calichon, D. Micol and A. Priolo, Effect $f$ grass or concentrate feeding system and rate of growth on triglycerides and phospholid and their fatty acids in the M. Longissumus thoracis of lambs., Meat Science 66 (2004), pp. 531 541.

S. Banni, G. Carta, M.S. Contini, E. Angioni, M. Deiana and M.A. Dessì et al., Characterization of conjugated diene fatty acids in milk, dairy products, and lamb tissues, Journal of Nutritional Biochemistry 7 (1996), pp. 150-155.

P. Bas and P. Morand-Fehr, Effect of nutritional factors on fatty acid composition of lamb fat deposits, Livestock Production Science 64 (2000), pp. 61-79.

D.E. Bauman and J.M. Griinari, Regulation and nutritional manipulation of milk fat: Lowfat milk syndrome. In: J.A. Mal and R.A. Clegg, Editors, Biology of the mammary gland, Kluver Academic/Plenum, New York (2000), pp. 209-216.

D.E. Baumann, A.L. Lock, B.A. Corl, C. Ip, A.M. Salter and P.W. Parodi, Milk fatty acids and human health: Potential role of Conjugated Linoleic Acid and trans fatty acids. In: K. Sejersen, T. Hvelplund and M.O. Nielsen, Editors, Ruminant physiology, Wageningen Academic Publishers (2006), p. 535.

M.A. Belury, Inhibition of carcinogenesis by Conjugated Linoleic Acid: Potential mechanisms of action, Journal of Nutrition 132 (10) (2002), pp. 295-2998.

M.J. Berian, A. Purroy, T. TReacher and P. Bas, Effect of animal and nutrition factors and nutrition on lamb meat quality. In: I. Ledin and P. Morand-Fehr, Editors, Sheep and goat nutrition: Intake, digestion, quality of products and rangelands, Zaragoza, Spain (2000).

L. Bernard, C. Leroux and Y. Chilliard, Characterisation and nutritional regulation of the main lipogenic genes in the ruminant mammary gland. In: K. Sejrsen, T. Hvelplund and M.O. Nielsen, Editors, Ruminant physiology, Wageningen Academic Publisher, TheNetherlands (2006), pp. 295-318.

W.W. Christie, A simple procedure for rapid transmethylation of glycerolipids and cholesteryl esters, Journal of Lipid Research 23 (1982), pp. 1072-1075. 
L. Delbecchi, C.E. Ahnadi, J.J. Kennelly and P. Lacasse, Milk fatty acid composition and mammary lipid metabolism in Holstein cows fed protected or unprotected canola seeds, Journal of Dairy Science 84 (6) (2001), pp. 1375-1381

G. Demirel, J.D. Wood and M. Enser, Conjugated Linoleic Acid content of the lamb muscle and liver fed different supplements, Small Ruminant Research 53 (2004), pp. 2328.

M.T. Diaz, I. Alvarez, J. De la Fuente, C. Sañudo, M.M. Campo and M.A. Oliver et al., Fatty acids composition of meat from typical lamb production systems of Spain, United Kingdom, Germany and Uruguay, Meat Science 71 (2005), pp. 256-263.

J.M. Griinari, B.A. Corl, S.H. Lacy, P.Y. Chouinard, K.V.V. Nurmela and D.E. Bauman, Conjugated Linoleic Acid is synthesised endogenously in lactating dairy cows by $\Delta^{9}$ desatusase, Journal of Nutrition 130 (2000), pp. 2285-2291.

C. Ip, S. Banni, E. Angioni, G. Carta, J. McGinley and H.J. Thompson et al., Conjugated Linoleic Acid enrich butter fat alters mammary gland morphogenesis and reduces cancer risk in rats, Journal of Nutrition 129 (1999), pp. 2135-2142.

J.A. Kelsey, B.A. Corl, R.J. Collier and D.E. Bauman, The effect of breed, parity and stage of lactation on Conjugated Linoleic Acid (CLA) in milk fat from dairy cows, Journal of Dairy Science 86 (2003), pp. 2588-2597.

T.A. Kokta, M.V. Dodson, A. Gertler and R.A. Hill, Intercellular signaling between adipose tissue and muscle tissue, Domestic Animal Endocrinology 27 (2004), pp. 303-331. J.K.G. Kramer, C. Cruz-Hernandez, Z.Y. Deng, J.Q. Zhou, G. Jahreis and M.E.R. Dugan, Analysis of Conjugated Linoleic Acid and trans 18:1 isomers in synthetic and animal products, American Journal of Clinical Nutrition 79 (2004), pp. 1137S-1145S.

J.K.G. Kramer, W. Parodi, R.G. Jensen, M.M. Mossoba, M.P. Yurawecz and R.O. Adlof, A proposed common name for the major Conjugated Linoleic Acid isomer found in natural products, Lipids 33 (1998), p. 835.

M. Lanza, M. Bella, A. Priolo, D. Barbagallo, V. Galofaro and C. Landi et al., Lamb meat quality as affect a natural or artificial milk feeling regime, Meat Science 73 (2006), pp. 313-318.

M. Lanza, M. Bella, A. Priolo, D. Barbagallo, V. Galofaro and C. Landi et al., Lamb meat quality as affected by natural or artificial milk feeding regimen, Meat Science 73 (2006), pp. 313-318. 
K.N. Lee, D. Kritcheviski and M.V. Pariza, Conjugated Linoleic Acid and atherosclerosis in rabbit, Atherosclerosis 108 (1994), pp. 19-25.

A.E.O. Malau-Aduli, B.D. Siebert, C.D.K. Bottema and W.S. Pitchford, Breed comparison of the fatty acid composition of muscle phospholipids in Jersey and Limousine Cattle, Journal of Animal Science 76 (1998), pp. 766-773.

M. Maranesi, D. Bochicchio, L. Mantellato, A. Zaghini, G. Pagliuca and A. Badiani, Effect of microwave cooking or broiling on selected nutrient contents, fatty acid patterns and true retention values in separable lean from lamb rib-loin, with emphasis on Conjugated Linoleic Acid, Food Chemistry 90 (1-2) (2005), pp. 207-218.

F. Napolitano, G.F. Cifuni, C. Pacelli, A.M. Riviezzi and A. Girolami, Effect of artificial rearing on lambs welfare and meat qualità, Meat Science 60 (2002), pp. 307-315.

K. Nurnberg, J. Wegner and K. Ender, Factors influencing fat composition in muscle and adipose tissue of farm animals, Livestock Production Science 56 (2) (1998), pp. 145-156.

G. Oriani, G. Maiorano, F. Filetti, C. Di Cesare, A. Manchisi and G. Salvatori, Effect of age on fatty acid composition of Italian Merino suckling lambs, Meat Science 71 (2005), pp. 557-562.

D.L. Palmquist, N. St-Pierre and K.E. McClure, Tissue fatty acid profiles can be used to quantify endogenous rumenic acid synthesis in lambs, Journal of Nutrition 134 (2004), pp. 2407-2414.

P.W. Parodi, Cows' milk fat components as potential anticarcinogenic agents, Journal of Nutrition 127 (1997), pp. 1055-1060.

A. Priolo, M. Lanza, V. Galofaro, V. Fasone and M. Bella, Partially or totally replacing soybean meal and maize by chickpeas in lamb diets: Intramuscular fatty acid composition, Animal Feed Science and Technology 108 (2003), pp. 215-221.

M.T. Rodriguez-Estrada, G. Penazzi, M.T. Caboni, G. Bertacco and G. Lercker, Effect of different cooking methods on some lipid and protein components of hamburgers, Meat Science 45 (1997), pp. 365-375.

J. Santos-Silva, R.J.B. Bessa and I.A. Mendes, The effect of supplementation with expanded sunflower seed on carcass and meat quality of lambs raised on pasture, Meat Science 65 (4) (2003), pp. 1301-1308.

J. Santos-Silva, R.J.B. Bessa and F. Santos-Silva, Effect of genotype, feeding system and slaughter weight on the quality of light lambs II. Fatty acid composition of meat, Livestock Production Science 77 (2-3) (2002), pp. 187-194. 
SAS, (1999). SAS User's Guide: Statistics, Version 8.0 Edition. SAS Inst. Inc., Cary, NC. N.D. Scollan, J-F. Hocquette, K. Nuernberg, D. Dannenberger, R.I. Richardson and A. Maloney, Innovation in beef production system that enhance the nutritional an health value of beef lipids and their relationship with meat quality, Meat Science 74 (2006), pp. 17-33.

P. Secchiari, M. Antongiovanni, M. Mele, A. Serra, A. Buccioni and G. Ferruzzi et al., Effect of kind of dietary fat on quality of milk fat from Italian Friesian cows, Livestock Production Science 83 (2003), pp. 43-52.

P. Secchiari, M. Mele, A. Serra, A. Buccioni, M. Antongiovanni and G. Ferruzzi et al., Conjugated Linoleic Acid (CLA) content in milk of three dairy sheep breeds, Progress in Nutrition 3-4 (2001), pp. 37-42.

P. Secchiari, M. Mele, A. Serra, A. Buccioni, F. Paoletti and A. Antongiovanni, Effect of breed, parity and stage of lactation on milk Conjugated Linoleic Acid in Italian Friesian and Reggiana cows, Italian Journal of Animal Science 2 (suppl. 1) (2003), pp. 269-271.

N. Sehat, M.P. Yurawecz, J.A.G. Roach, M.M. Mossoba, J.K.G. Kramer and K. Ku, Silver ion High Performance Liquid Chromatographic separation and identification of Conjugated Linoleic Acid isomers, Lipids 33 (1998), pp. 217-221.

M. Taniguchi, T. Utsugi, K. Oyama, H. Mannen, M. Kobayashi and Y. Tanabe et al., Genotype of stearoyl-CoA desaturase is associated with fatty acid composition in Japanese black cattle, Mammalian Genome 15 (2) (2004), pp. 142-148.

E. Tsiplakou, K.C. Mountzouris and G. Zervas, Concentration of Conjugated Linoleic Acid in grazing sheep and goat milk fat, Livestock Science 103 (2006), pp. 74-84.

M.A. Valvo, M. Lanza, M. Bella, V. Fasone, M. Scerra and L. Biondi et al., Effect of ewe feeling system (grass v. concentrate) on intramuscular fatty acids of lambs raised exclusively on maternal milk, Animal Science 81 (2005), pp. 431-436.

S. Velasco, V. Caneque, C. Pérez, S. Lururica, M.T. Diaz and F. Huidobro et al., Fatty acid composition of adipose depots of suckling lambs raised under different production systems, Meat Science 59 (2001), pp. 325-333.

R.L. Wolf and C.C. Bayard, Improvement in the resolution of individual trans-18:1 isomers by capillary gas liquid chromatography: Use of a $100 \mathrm{~m}$ CP-Sil 88 column, Journal of the American Oil Chemists Society. AOCS. 72 (1995), pp. 1197-1201.

J.D. Wood, M. Enser, A.V. Fisher, G.R. Nute, P.R. Shear and R.I. Richardon et al., Fat deposition, fatty acids composition and meat quality: A review, Meat Science 78 (2008), pp. 343-358. 